\title{
Turonian-Coniacian (Upper Cretaceous) of the Babadag Basin (North Dobrogea, Romania): integrated biostratigraphy and microfacies succession
}

\author{
Damian Gerard LODOWSKI" * , Ireneusz Piotr WALASZCZYK ${ }^{1}$ and Eugen GRĂDINARU², * \\ 1 University of Warsaw, Faculty of Geology, Żwirki i Wigury 93, 02-089 Warszawa, Poland \\ 2 University of Bucharest, Department of Geology, 1 Bălcescu Nicolae Blvd., Bucharest, Romania
}

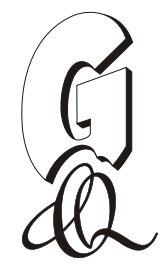

\begin{abstract}
Lodowski, D.G., Walaszczyk, I.P., Grădinaru, E., 2019. Turonian-Coniacian (Upper Cretaceous) of the Babadag Basin (North Dobrogea, Romania): integrated biostratigraphy and microfacies succession. Geological Quarterly, 63 (1): 39-64, doi: 10.7306/gq.1452

The Upper Turonian to Middle Coniacian (Upper Cretaceous) succession of the Babadag Basin (North Dobrogea, Romania) constitutes an apparently continuous fossiliferous carbonate succession. The presence of moderately rich inoceramid, ammonite and foraminiferal assemblages allows for the application of a precise biostratigraphic subdivision. The palaeoenvironmental conditions and evolution of the Babadag Basin during the Late Turonian-Middle Coniacian are inferred using microfacies analysis and foraminiferal spectra. Together, these suggest the Turonian-Coniacian Badabag Basin reflects relatively shallow-water conditions in a near-shore environment, punctuated by two regression events in the Late Turonian and in the Middle Coniacian.
\end{abstract}

Key words: microfacies, petrology, inoceramids, ammonites, foraminifera, palaeoenvironment.

\section{INTRODUCTION}

The Turonian-Coniacian succession of the Babadag Basin (North Dobrogea, Romania) has long attracted research interest, due to its rich ammonite and inoceramid fauna and its location in the western part of a belt comprising North Dobrogea, the Crimea, and the northern Caucasus (e.g., Săndulescu, 1994). To date, work within the Babadag Basin has focused on broader stratigraphic studies, and therefore has yielded only a limited insight into the succession and structure of the fossil assemblages. Moreover, only limited work has been done on the facies characteristics of the stratigraphic succession, which have the potential to add substantially to our understanding of the dynamic evolution of the Babadag Basin. A joint integrated biostratigraphic and microfacies study of the Turonian-Coniacian Babadag Basin, to examine its palaeontological and palaeoenvironmental setting, thus constitutes the primary focus of the present study.

In the framework of a joint project between the University of Bucharest and University of Warsaw, aimed at the re-study of the stratigraphy and facies of the early Late Cretaceous succession in Romania, we investigated the Upper Turonian to Middle Coniacian succession of the Babadag Basin. Three quarries located in the southeastern part of the Babadag Basin were se-

\footnotetext{
* Corresponding authors, e-mail: damian.lodowski@student.uw.edu.pl; egradinaru@gmail.com Received: July 20, 2018; accepted: November 22, 2018; first published online: February 22, 2019
}

lected for detailed study: (1) the Visterna section, south of the village of Visterna; (2) the Caugagia section, located north-west of the village of Baia, and (3) the Baia section, located north-east of the village of Baia (Figs. 1 and 2). These three sections comprise an interval spanning the Upper Turonian through the Middle Coniacian, with some observational gaps. The main goals of the study were to develop: (1) detailed geological logs; (2) macrofossil and foraminiferal records, for use in biostratigraphic and palaeoenvironmental interpretations; and (3) microfacies characteristics of the entire succession. The combination of the palaeontological and microfacies characteristics of the succession was used to reconstruct the bathymetric trends within the interval studied. The palaeogeographical inferences are discussed.

\section{PREVIOUS STUDIES}

The Cretaceous of the Babadag Basin was first studied by Peters (1867), who described a crinoid limestone in the basal part of the succession followed by a yellowish "distal limestone". Inoceramids, foraminifers, oysters and burrows were reported. He estimated the thickness of the succession as ca. $170 \mathrm{~m}$. Anastasiu (1898) realized that the flat-lying or slightly undulating Upper Cretaceous occupies most of the basin. He documented both the Turonian and Coniacian, and suggested the presence of the Cenomanian. The presence of the Coniacian was further confirmed by Macovei (1906) using ammonite assemblages. Simionescu (1914) divided the Cretaceous of the Badabag Basin into the lancila Formation (lower), composed of conglomerates, calcarenites and limestone, and the Dolojman 


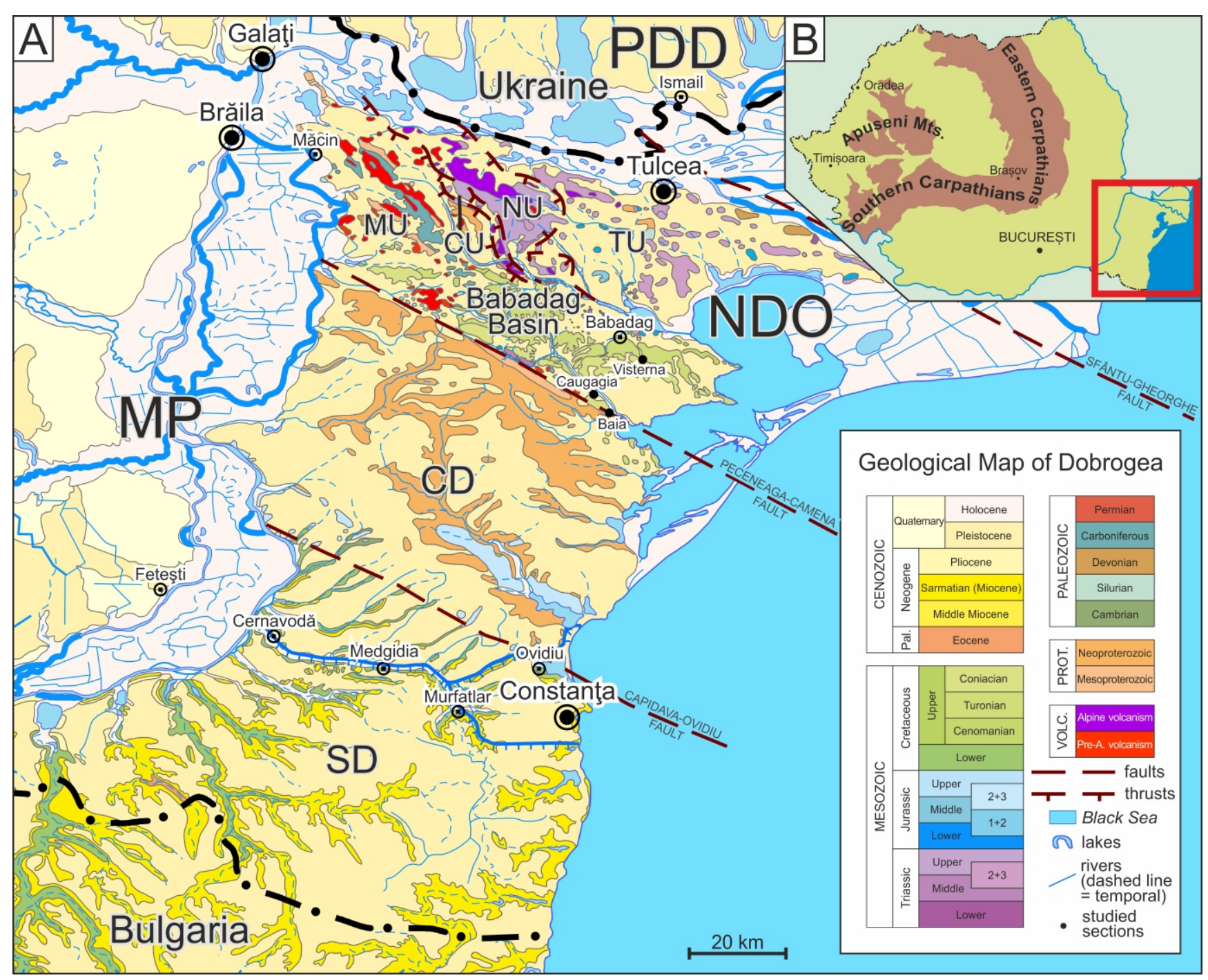

Fig. 1A - geological map of Dobrogea (compiled and modified after Săndulescu et al., 1978; Szász et al., 1980, 1981) with the location of the Babadag Basin; B - location of Dobrogea in Romania

NDO - North Dobrogea Orogen, including the tectonic units of Măcin (MU), Consul (CU), Niculiţel (NU) and Tulcea (TU); MP - Moesian Platform, including Central Dobrogea (CD) and South Dobrogea (SD); PDD - Pre-Dobrogean Depression; PROT. - Proterozoic; VOLC. - volcanic rocks; Pre-A. - Pre-Alpine; Pal. - Paleogene

Formation (upper), composed of calcarenites, sandy marls, marls and limestones. Based on macrofossils, he assigned the lancila Formation to the Cenomanian, and the Dolojman Formation to the Turonian-Senonian. In his geological synthesis of Dobrogea, Simionescu (1927) established that the basin is bounded to the south by the Peceneaga-Camena Fault. For the first time he reported the presence of Cretaceous echinoids and Cenomanian inoceramids from this region.

Macovei and Atanasiu (1934) summarized the Cretaceous succession of the Babadag Basin, estimating its thickness as ca. $200 \mathrm{~m}$ and dating the youngest strata as Santonian. Atanasiu (1940) pointed out the differences in the Late Cretaceous palaeogeographical history of North and South Dobrogea, reporting warm-water faunas in the Babadag Basin, in contrast to cold-water faunas in South Dobrogea.

In their survey of the Babadag Basin, Mirăuţă and Mirăuţă (1964) recognized four synclines, two anticlines and one structural threshold, and estimated the thickness of the Cretaceous as $300-350 \mathrm{~m}$. They divided the Dolojman Formation into two successions, the lower dated as Early Turonian, and the upper, dated as the Middle-Late Turonian-Coniacian and possibly Santonian (their Lower Senonian). They recognized the transgressive character of the Upper Cretaceous succession, with the transgressive maximum occurring in the Early Santonian. They also noted the dominance of the Boreal faunas, with only a few Tethyan forms present, and the distinctiveness of the Cretaceous successions between North and South Dobrogea, the succession in North Dobrogea being thicker and stratigraphically more complete. Mutihac et al. (1972) claimed a Late Aptian-Albian age for the basal part of the Babadag succession. Szász and Lăcătuşu (1976) and Szász (1981) reported on the Upper Turonian-Coniacian ammonites from the Babadag Basin, and in 1985 Szász published a survey of the Coniacian inoceramids. Szász and lon (1988) provided an integrated (inoceramid, ammonite and foraminifera) biostratigraphy of the Upper Cretaceous of the Babadag Basin, in which the Turonian-Coniacian boundary was considered as condensed or marked by a stratigraphic gap. Furthermore, they showed the 


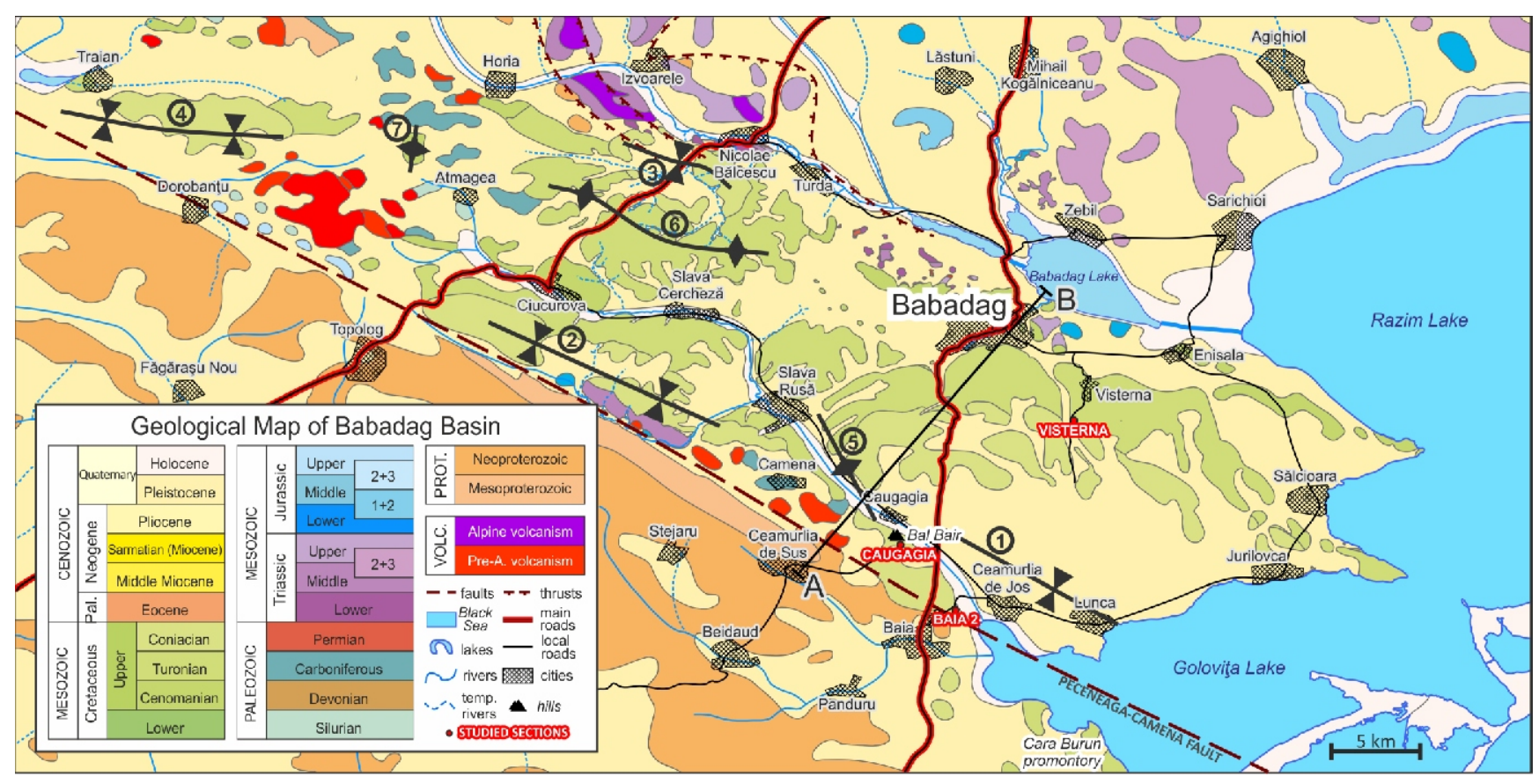

Fig. 2. Geological map of Babadag Basin (compiled and modified after Mirăuţă and Mirăuţă, 1964; Săndulescu et al., 1978; Szász et al., 1980, 1981)

Bold black lines with arrows are the synclines and anticlines axes: 1 - Caugagia-Jurilovca Syncline; 2 - Başpunar-Uspenia Syncline; 3 - Bălcescu Brachisyncline; 4 - Izvoarele-Traian Syncline; 5 - Slava Rusă Anticline; 6 - Jidini Anticline; 7 - Atmagea Threshold; A-B - line of geological cross-section (Fig. 3); other explanations as in Figure 1

presence of the Upper Santonian and estimated the thickness of the Upper Cretaceous as ca. $700 \mathrm{~m}$.

The ammonite and inoceramid biozonation and biogeographical affinities of the Turonian and Coniacian of the Babadag Basin were discussed by lon and Szász (1994). The authors observed a general agreement between the Western Europe and North Dobrogea zonations. The Tethyan character of the foraminifera was indicated. Ion et al. (1997) published an integrated biostratigraphy of the Upper Cretaceous of Romania, and lon et al. (2004) an integrated biostratigraphy of the Turonian. With reference to the results of the Brussels '95 meeting (Bengtson, 1996), they found their zonations to be generally compatible, but not identical with the standard zonation. Bucur and Baltreş (2002) conducted a study of Cenomanian microfossils based on borehole core data. Grădinaru (2004) and Grădinaru et al. (2006) showed that the sedimentation into the Babadg Basin started in the Late Albian (Vraconian).

\section{GEOLOGICAL SETTING}

The Cretaceous Babadag Basin represents the post-tectonic, latest Albian (Vraconian) to Late Cretaceous sedimentary cover of the Early Alpine North Dobrogea Orogen (e.g., Burchfiel and Bleahu, 1976; Săndulescu, 1984; Grădinaru, 1995). It is located south of the Danube Delta, in SE Romania (Fig. 1). Eastward, the basin plunges into the continental shelf of the Black Sea (e.g., Săndulescu, 1984; Ionesi, 1994; Băncilă et al., 1997). The northern boundary of the basin is erosional. Along its southern margin, the basin is tectonically bounded by the Peceneaga-Camena Fault, although toward the east in the
Baia region, the Upper Cretaceous deposits of the basin apparently seal the fault (Grădinaru, 1995).

The basement of the Babadag Basin is chiefly composed of the three major tectonic units of the Early Alpine North Dobrogean Orogen, the Măcin, Niculiţel and Tulcea units, which are composed of Precambrian-Paleozoic metamorphic rocks and granitoids and Triassic-Jurassic volcanic and sedimentary rocks. For further information on the geology of the pre-Cretaceous basement of the Babadag Basin along the northern side of the Peceneaga-Camena Fault the reader is advised to consult the publications of Grădinaru $(1988,2006)$ The Central Dobrogea Neoproterozoic greenschist basement underlies the Babadag Basin south of the Peceneaga-Camena Fault in the Baia region (Mirăuţă and Mirăuţă, 1964). The Peceneaga-Camena Fault is interpreted as the southern part of the Teisseyre-Tornquist line (T-T line; e.g., Ziegler, 1984, 1988; Robinson, 1997; Świdrowska et al., 2008).

Recent studies (Krezsek et al., 2018) interpret the area between the Sfântu-Gheorghe Fault in the north (the boundary between North Dobrogea and the Pre-Dobrogea Depression) and the Capidava-Ovidiu Fault in the south (the boundary between Central and South Dobrogea) as a strike-slip deformation belt. These deformation structures are considered to be an abandoned arm of the initial stage of the Western Black Sea rifting, which took place in the Middle and Late Cretaceous. In this case, the Peceneaga-Camena Fault was the main fault within the deformation zone, while the other faults in the region are believed to be its deeply buried branches. Along the North Dobrogean failed-rift zone, on the offshore prolongation of the Babadag Basin, another depocentre - the Istria Depression developed (Krezsek et al., 2018; Boote, 2018). 


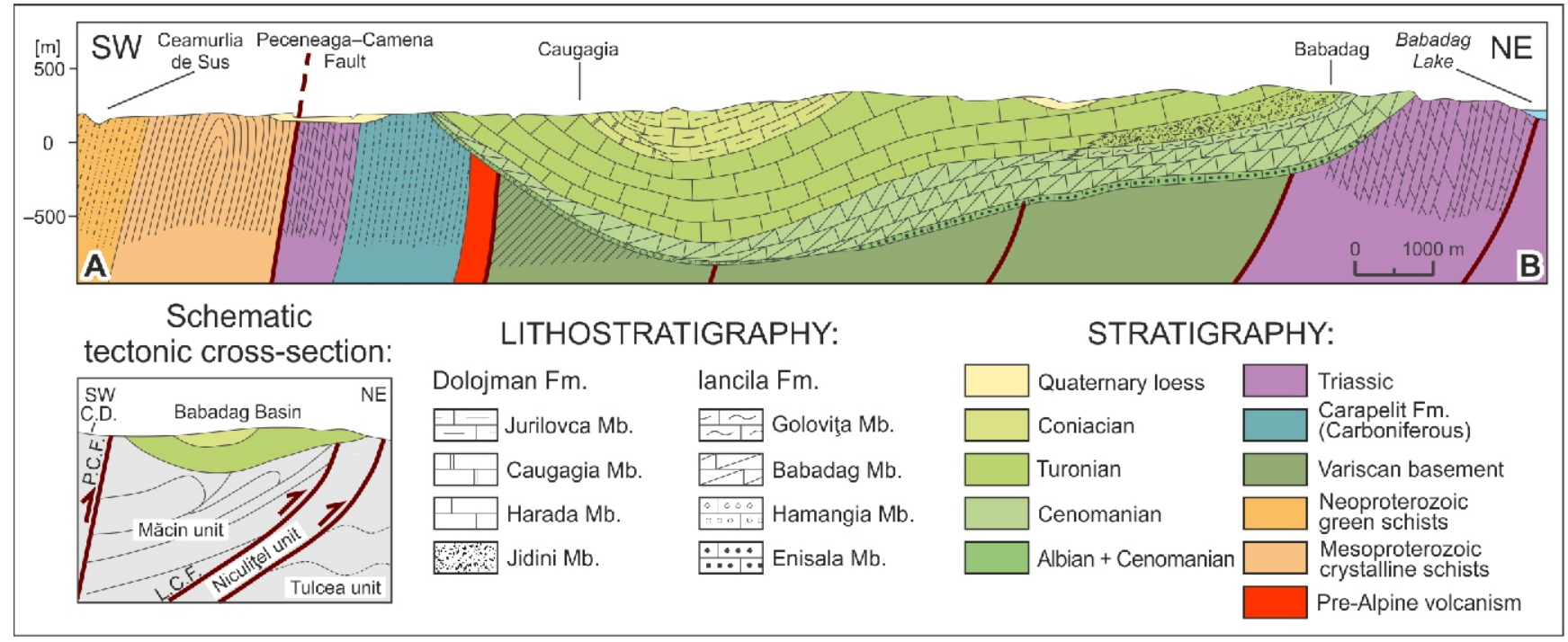

Fig. 3. Geological A-B cross-section through the Babadag Basin and schematic deep tectonics cross-section (compiled and modified after Mirăuţă and Mirăuţă, 1964; Szász and Ion, 1988)

For the updated geology of the pre-Cretaceous basement along the northern side of the Peceneaga-Camena Fault see Grădinaru (1988, 2006); dark red bold lines - faults; C.D. - Central Dobrogea; P.C.F. - Peceneaga-Camena Fault; L.C.F. - Luncaviţa-Consul Fault

\section{BABADAG BASIN}

The Babadag Basin, $60 \mathrm{~km}$ long (along a northwestern-southeastern axis) and up to $20 \mathrm{~km}$ wide at its maximum extent, is filled with uppermost Albian to Santonian deposits. Despite a generally flat-lying character, the basin is slightly undulating, creating four synclines arranged around the basin center: Izvoarele-Traian to the west, Bălcescu to the north, Başpunar-Uspenia located to the south, and Caugagia-Jurilovca to the east. In the western part of the basin its axis emerges, forming the Izvoarele-Atmagea threshold. This structure separates the Izvoarele-Traian Syncline on the west from the rest of the basin (Mirăuţă and Mirăuţă, 1964; Fig. 2).

The thickness of the Cretaceous in the Babadag Basin is quite variable, fluctuating from slightly above $1600 \mathrm{~m}$ in its north-central part to $266 \mathrm{~m}$ only $4.5 \mathrm{~km}$ SE of the depocentre (Bucur and Baltreş, 2002). Previously published estimates range between 350 m (Mirăuţă and Mirăuţă, 1964) and 700 m (Szász and lon, 1988). Krezsek et al. (2018) interpret the basin as slightly inclined to the SE, which is in agreement with the migration of the basin's depocentre to the south as observed by Mirăuță and Mirăuță (1964; Fig. 3). However, the structural framework of the Babadag Basin seems to be somewhat more complicated.

The Babadag Basin succession (Fig. 3) first appears in the Enisala area as an uppermost Albian (Vraconian) crinoidal limestone with brachiopods, ammonites and oysters (Grădinaru, 2004; Grădinaru et al., 2006). It is followed by transgressive Cenomanian calcarenites, locally with limestones and marls (Mirăuţă and Mirăuţă, 1964; Szász and Ion, 1988). The Upper Cenomanian is condensed. The biostratigraphy of the Cenomanian is based on ammonites, inoceramids, and planktonic foraminifera (Szász, 1982; Szász and Ion, 1988; Ion and Szász, 1994; Ion et al., 1997). The Albian-Cenomanian succession forms the lancila Formation, which is subdivided into the Enisala Member (Albian-Lower Cenomanian siliciclastic deposits and limestones), the Hamangia Member (Lower Cenomanian siliciclastic deposits and calcarenites), the Babadag Member (Lower-Upper Cenomanian calcarenites and limestones) and the Goloviţa Member (Middle-Upper Cenomanian marls; Szász and Ion, 1988). The Babadag Turonian strata (composed of calcarenites, limestones and marls) conformably overlie the Cenomanian: however, the boundary interval is condensed and transgressive in the marginal part of the basin (Szász and lon, 1988). A hiatus within the Middle Turonian and a condensation or hiatus within the Upper Turonian-Lower Coniacian have been suggested (Szász and Ion, 1988). The Coniacian consists of calcarenites and marly limestones: however, in the marginal parts of the basin the Turonian strata are transgressively overlain by Coniacian conglomerates (Mirăuţă and Mirăuţă, 1964; Szász and Ion, 1988). The biostratigraphy of the Turonian and of the Coniacian is based on ammonites, inoceramids and planktonic foraminifera (Szász and Ion, 1988; Ion and Szász, 1994; Ion et al., 1997, 2004). The Turonian-Coniacian succession is assigned to the Dolojman Formation, which consists of: the Jidini Member (Lower to Middle Turonian calcarenites and siliciclastic deposits), the Harada Member (Turonian limestones and calcarenites), the Caugagia Member (Lower Coniacian calcarenites), and the Jurilovca Member (Coniacian (?) limestones, marly limestones and calcarenites); the Jidini and Caugagia members represent more clastic facies (Szász and Ion, 1988). On the Cara Burun promontory, south of Goloviţa Lake (Fig. 2), the Coniacian strata are overlain by Santonian strata, which consist of basal conglomerates followed by limestones. The Santonian of this region is included in the Murfatlar Formation, originally described from South Dobrogea (Szász and Ion, 1988).

\section{MATERIALS AND METHODS}

The present study is based on our original fieldwork carried out in the Babadag Basin in summer 2016. Three sections located in the southeastern part of the basin - Visterna, Caugagia and Baia 2 - were logged and sampled for macrofossils, microfossils, and petrographic analyses. 
Laboratory work was conducted in the Faculty of Geology of the University of Warsaw. 114 thin sections were prepared (usually two thin sections from each suitable rock sample): 67 from Visterna, 4 from Caugagia and 42 from Baia 2. All thin sections were prepared in the Laboratory of Geological Sample Preparation of the European Center for Geological Education (ECEG) in Chęciny (affiliated with the University of Warsaw), Poland, using a Logitech PM5 Lapping \& Polishing System and Epotek Epoxy glue. Porous samples were additionally impregnated using Araldite 2020 glue and UV pigment. The thin sections were used for microfacies and micropaleontological studies.

The microfacies analysis was primarily based on the Folk and Dunham classification schemes. As these were not fully satisfactory, a custom microfacies classification was developed (see "microfacies" section). Thin sections were assessed with regard to grain size, roundness and sorting, clastic input, quartz content, rock texture (directional/chaotic), and observed fossils. Clastic input and quartz content estimations were conducted using Compton's standard visual estimating charts (Compton, 1962), sorting was estimated using Jerram et al. sorting charts (1996). Roundness observations were based on (Pettijohn et al., 1987) roundness estimation charts. Grain size estimations were employed only on the non-biogenic clasts.

Foraminiferal macerates were prepared from thirty-five samples from Visterna and from twenty-one samples from Baia 2. A standard procedure using sodium sulphate (Glauber's salt) was employed. To accelerate the maceration process, the freezing was accelerated using liquid nitrogen (Remin et al., 2012). The macerates obtained were sifted to obtain material in the $0.065-0.6 \mathrm{~mm}$ size interval. The foraminifera were studied using an optical microscope; selected specimens were sputtered with gold for SEM (Scanning Electron Microscope) imaging and EDS (Energy-dispersive X-ray spectroscopy) analysis. EDS analysis was used to assess if the calcareous foraminiferal tests were composed of primary calcite, and so whether they had been affected by diagenetic alteration.
The macrofossils collected during our fieldwork (ammonites and inoceramids) and microfossils (foraminifera), are housed in the collections of the Museum of the Faculty of Geology of the University of Warsaw.

\section{FIELD OBSERVATIONS}

The sections studied are located in the southeastern part of the basin. Three sections were selected for the study: the Visterna section, located in the eastern part, and the Caugagia and Baia 2 sections, both located in the southern part of the ba$\sin$ (Fig. 2).

Visterna section $\left(44^{\circ} 50^{\prime} 35^{\prime \prime} \mathrm{N}, 28^{\circ} 45^{\prime} 39^{\prime \prime} \mathrm{E} ; 116.5 \mathrm{~m}\right.$ a.s.I.) (Figs. 2 and 4). The Visterna section is located in an active village quarry, south of the village of Visterna. The quarry is $96 \mathrm{~m}$ long, $33 \mathrm{~m}$ wide, with the walls reaching a maximum of $3 \mathrm{~m}$ in height. The exposure is generally good. The beds dip to the south $(115 / 6 \mathrm{~S})$. The total thickness of the available succession is $13 \mathrm{~m}$, with a ca. $70 \mathrm{~cm}$ observational gap in its lower part. Ten lithological units were distinguished in the succession (Fig. 5).

Unit 1 [0-5.1 m]: heavily lithified, poorly and/or thinly bedded, fine-grained light grey limestone. It is relatively rich in ammonites and inoceramids.

Unit 2 [5.1-7.85 m]: basal part composed of hard, sparkling, medium-bedded, fine-grained grey limestone. Higher part (5.4-7.35 m) composed of thin-bedded, fine-grained limestone and calcarenite with sponges, bioturbation structures and pelitic clasts; the uppermost part composed mostly of very hard, bright, well-bedded calcarenite. A $10 \mathrm{~cm}$ thick layer of slaty grey marl occurs at $6.3 \mathrm{~m}$, and a $5 \mathrm{~cm}$ thick layer of light grey marl occurs at $7.35 \mathrm{~m}$

Unit 3 [7.85-8.4 m]: loose grey marls; interbedded with $10 \mathrm{~cm}$ thick layers of bedded calcarenite.

Unit 4 [8.4-10.3 m]: lowermost $10 \mathrm{~cm}$ composed of thin-bedded, sparkling, fine-grained grey limestone. Middle part

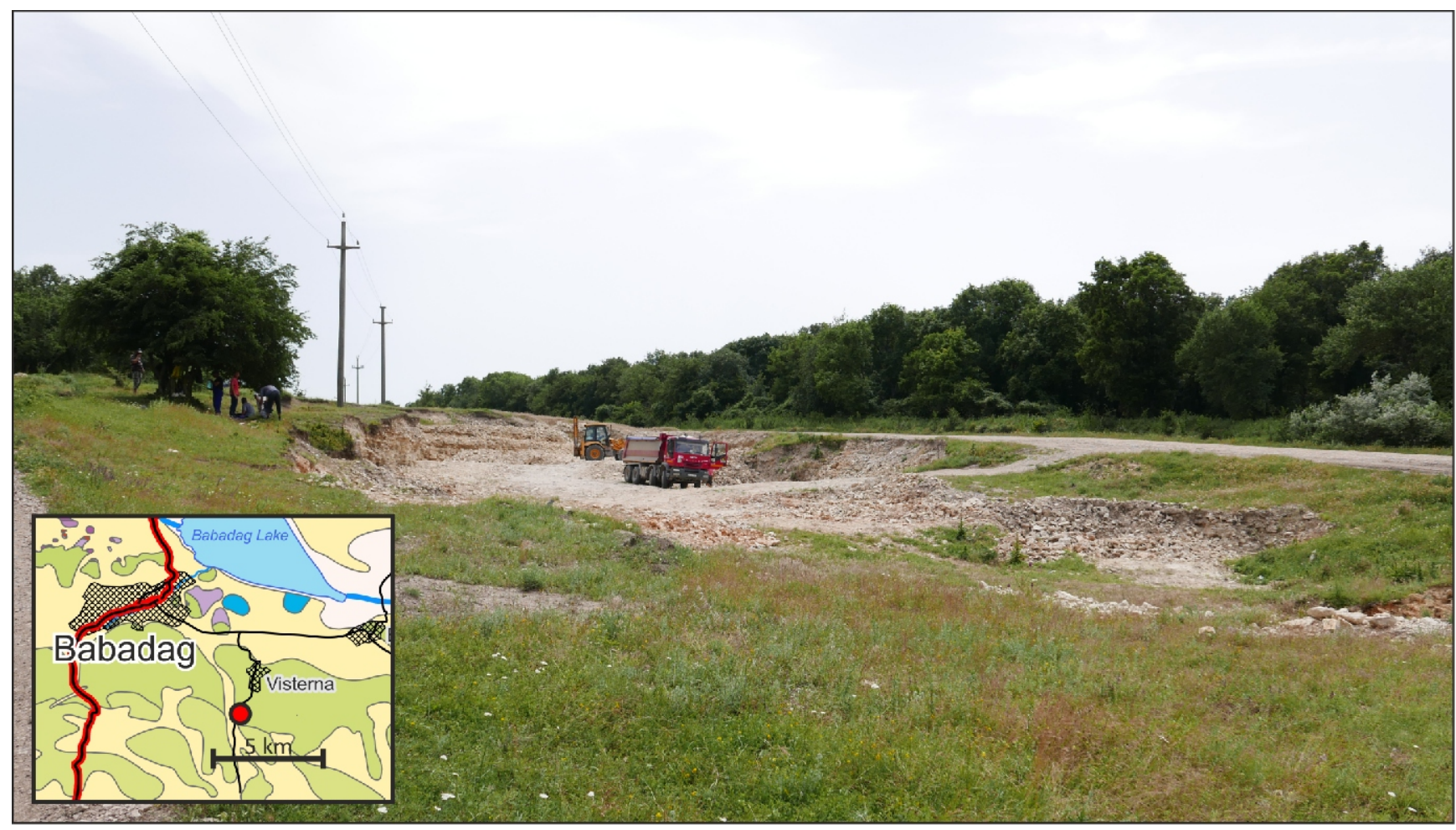

Fig. 4. Visterna Quarry and location on the geological map of the Babadag Basin (red dot) 


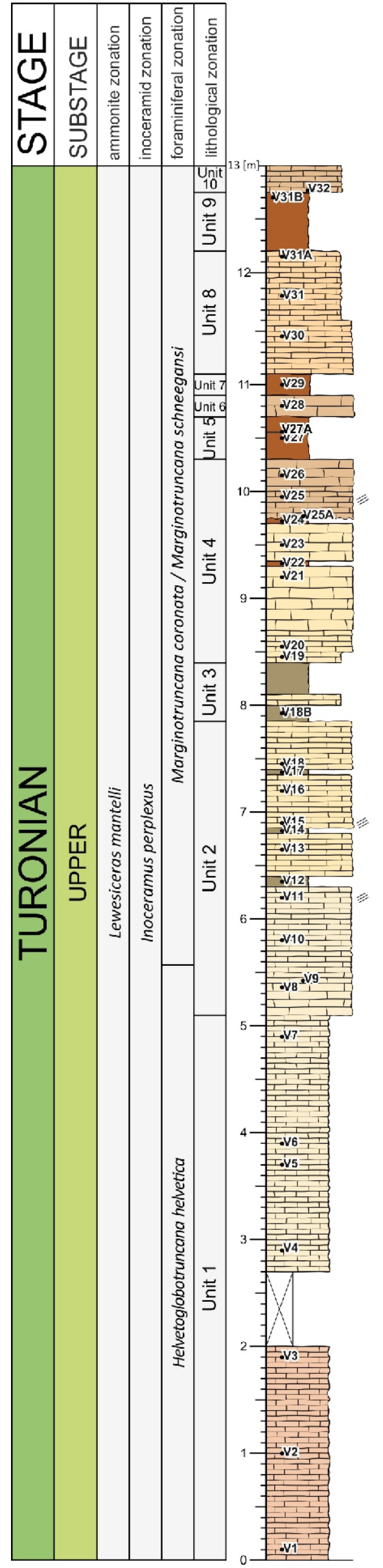

of the unit composed of hard, massive, fine-grained beige or light grey limestone with intermittent pelitic clasts, interbedded with grey marls. At $9.75 \mathrm{~m}$ there is an erosional surface at the top of a marly layer. Topmost part composed of hard, sparkling, bedded, beige calcarenite, followed by very fine-grained grey limestone with pelitic clasts.

Unit 5 [10.3-10.7 m]: light grey marls. $2.5 \mathrm{~cm}$ thick condensation level (V27A) at $10.55 \mathrm{~m}$.

Unit 6 [10.7-10.9 m]: very fine-grained grey limestone with pelitic clasts.

Unit 7 [10.9-11.1 m]: grey marls.

Unit 8 [11.1-12.2 m]: sparkling, fine-grained beige limestone, overlain by hard, sparkling, very fine-grained grey limestone with jagged fracture.

Unit 9 [12.2-12.75 m]: grey marls.

Unit 10 [12.75-13.0 m]: sparkling, fine-grained grey limestone with earthy fracture.

Caugagia section $\left(44^{\circ} 46^{\prime} 35^{\prime \prime} \mathrm{N}, 2^{\circ} 40^{\prime} 02^{\prime \prime} \mathrm{E}\right.$; Figs. 2 and 6 ) is a composite section, compiled from two small quarries located on Bal Bair hill, about $2 \mathrm{~km}$ south from the village of Caugagia. The succession is made up of light grey (Caugagia 1, south-west quarry) and light creamy/white (Caugagia 2, north-east quarry) pelitic limestone. No detailed geological log was constructed

Baia 2 section ( $44^{\circ} 44^{\prime} 25^{\prime \prime} \mathrm{N}, 28^{\circ} 41^{\prime} 50^{\prime \prime} \mathrm{E}$; Figs. 2 and 7$)$ is an active quarry, located between Baia and Ceamurlia de Jos, north-east of the village of Baia. The quarry is $77 \mathrm{~m}$ long, $64 \mathrm{~m}$ wide and about $11 \mathrm{~m}$ high. The succession is available on its northern, eastern and southern walls, with a good state of exposure. The beds dip to the south $(22 / 5 \mathrm{~S})$. The total thickness of the succession is $10.5 \mathrm{~m}$. Seven lithological units were distinguished (Fig. 8); 21 samples $\left(B_{2} 1-B_{2} 18\right)$ for microfacies and microfossil studies were taken.

Unit 1 [0.0-5.5 m]: hard, splintery and massive marly limestone, with numerous iron streaks. Common bioturbation structures at the top of the unit.

Unit 2 [5.5-5.7 m]: hard, bedded, fine-grained brown limestone with cherts. Thickness is horizontally variable, with a maximum thickness of $17 \mathrm{~cm}$. Overlain by a $3 \mathrm{~cm}$ thick layer of cross-bedded, grey-green marls.

Unit 3 [5.7-6.6 m; eastern wall]: hard, bright, splintery, cross-bedded, fine-grained limestone with thickness laterally variable from 8 to $30 \mathrm{~cm}$, with $2 \mathrm{~cm}$ thick marly interbeds. In the southern wall, fine-grained light grey limestone with numerous iron streaks are followed by a $15 \mathrm{~cm}$ thick intraformational breccia.

Unit 4 [6.6-6.93 m; eastern wall]: bedded, thinly laminated, fine-grained beige-grey limestone with cherts and laterally variable thickness, followed by a thin ( $3-5 \mathrm{~cm}$ thick) layer of grey marl. The southern wall shows sparkling, thin- and cross-bedded, beige-brown calcarenite with ripple marks.

Unit 5 [6.93-10.2 m; eastern wall]: heavily bioturbated, very fine-grained creamy limestone.

Unit 6 [10.2-10.28 m]: grey-green marls.

Unit 7 [10.28-10.5 m]: sparkling, grey limestone with milky fracture.

Fig. 5. Geological log and biostratigraphy of the Visterna Quarry

Colours on the lithological logs refer to actual colours observed in the quarry; layer thickness has been preserved 


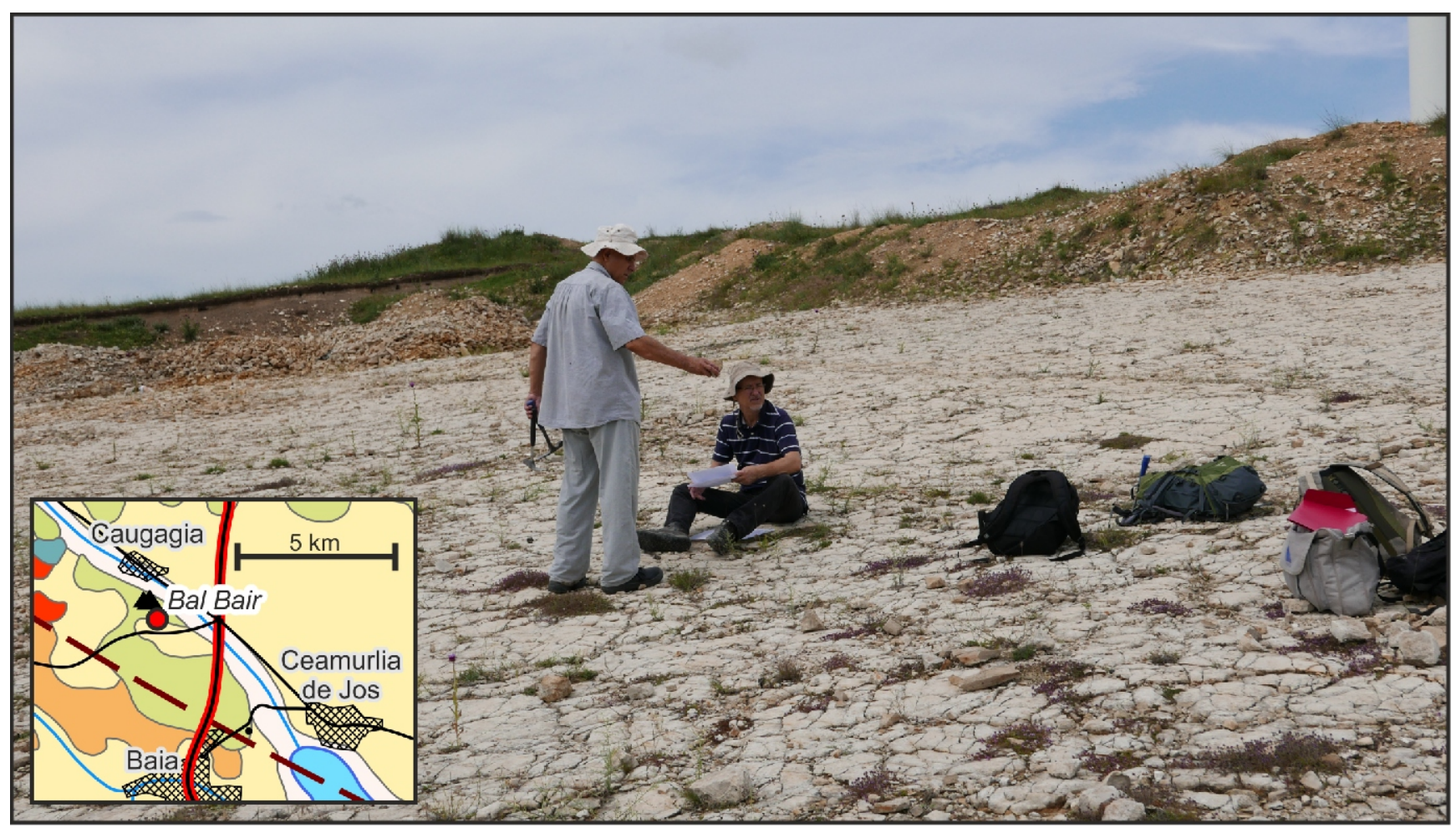

Fig. 6. Caugagia Quarry and location on the geological map of the Babadag Basin (red dot) Bal Bair hilltop is to the right of the photo

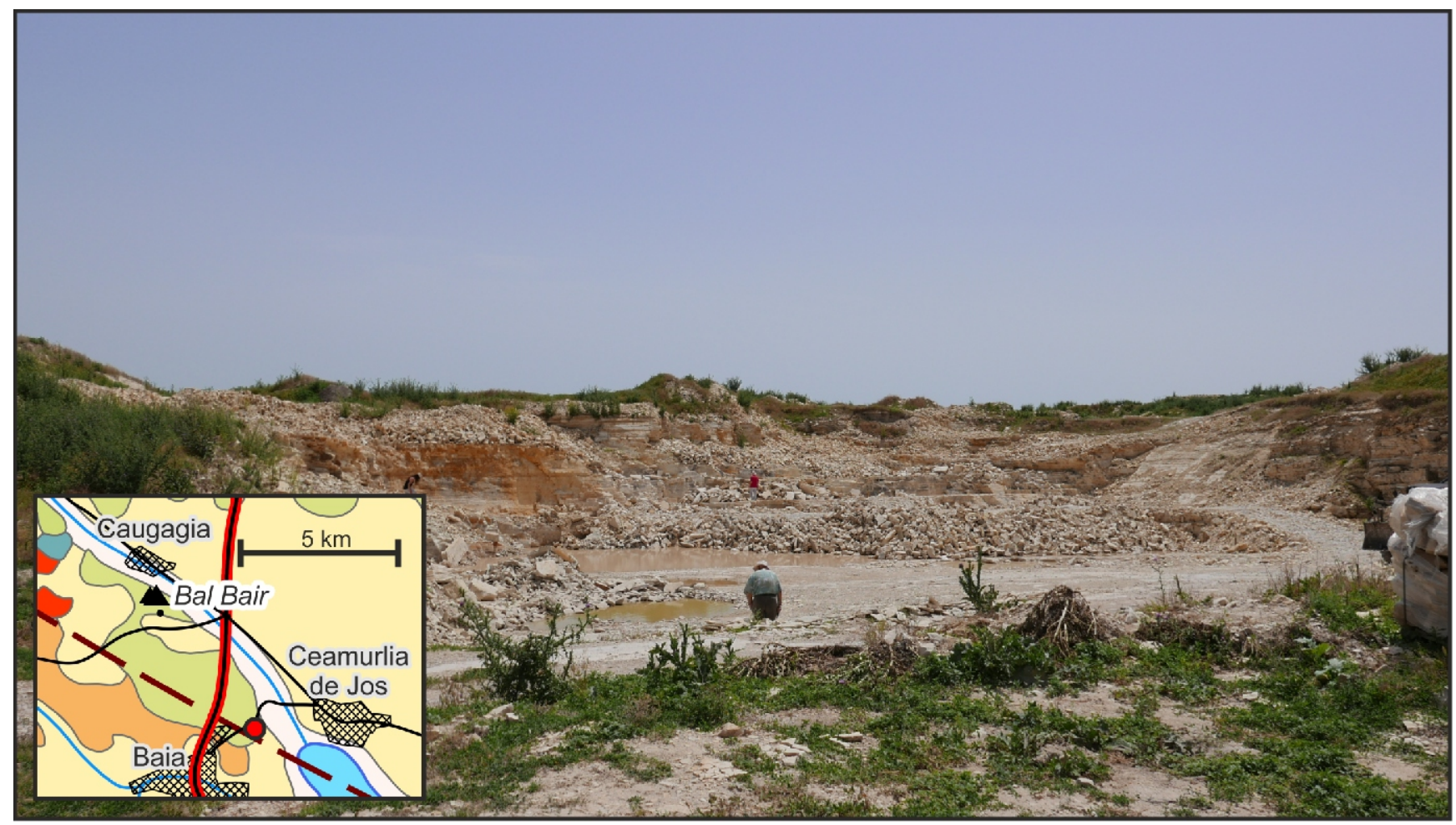

Fig. 7. Baia 2 Quarry and location on the geological map of the Babadag Basin (red dot)

View towards the southern wall of the quarry 


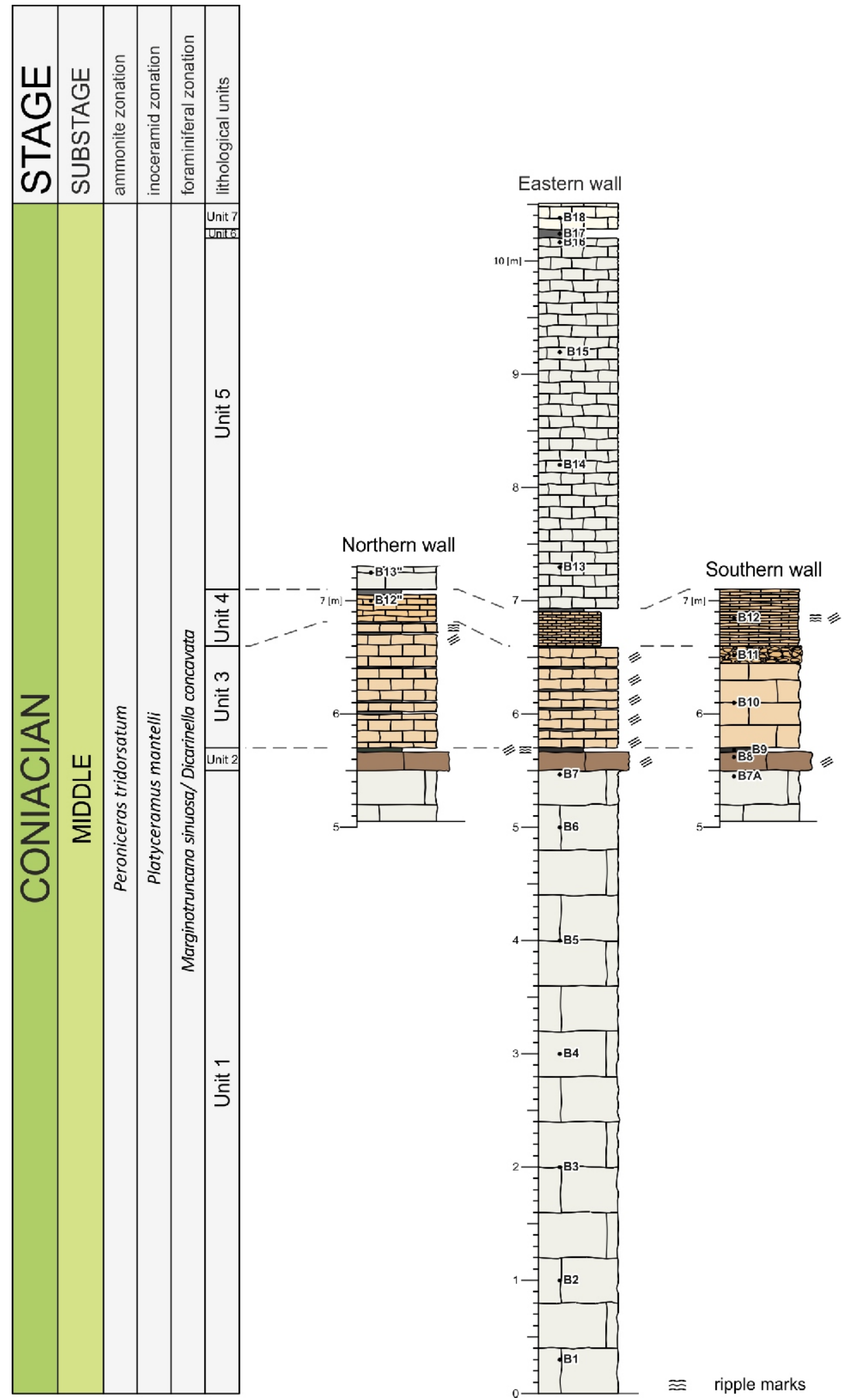

Fig. 8. Geological logs and biostratigraphy of the Baia 2 Quarry

Colours on the lithological logs refer to actual colors observed in the quarry; layer thickness has been preserved; other explanations as in Figure 5 


\section{MICROFACIES}

Six microfacies were distinguished: (I) sedimentary breccia; (II) non- to poorly fossiliferous mudstone/wackestone/packstone; (III) fossiliferous wackestone/packstone, subdivided as follows: (IIIA) bioclastic (with diverse faunal composition) wackestone/packstone; (IIIB) foraminiferal (dominated by forams, with abundant other fossils) wackestone/packstone (IIIC) foraminiferal (almost no other fauna) wackestone/packstone; (IIID) algae dominant or algal-sponge wackestone/packstone (Fig. 9). Detailed microfacies are outlined in Table 1 (Visterna) and Table 2 (Baia 2).

\section{VISTERNA SECTION}

Unit 1 is composed of wackestones and wackestones/packstones. The samples are moderately rich in quartz and fossils, in which foraminifera and calcareous algae (mostly Dasycladaceae) dominate.

Units 2-4 are composed primarily of barren or poorly fossiliferous packstones. Within this interval are relatively large grain diameters (highest in the V25 sample) and high (up to $30 \%$ ) proportions of quartz in samples are typical. In the middle part of the unit the wackestone/packstone and wackestone microfacies dominate. The percentage of quartz in these is lower (up to 10\%) than in the interbedded packstones (up to $25 \%$ ), yet they are more fossiliferous and dominated by foraminifera, calcareous algae and sponges (spiculites). A very sharp, erosive boundary between layers V24 and V25 is characteristic of this interval (see Fig. 10).

Units 5-10 are composed of moderately fossiliferous wackestones, with mainly foraminifera, sponges and calcareous algae. The detrital material is usually fine- or very fine-grained, with low quartz contents. In addition, wackestones/packstones (V32 sample) and packstones (V30 sample) occur, with variable quartz contents.

\section{CAUGAGIA}

The succession is represented by quartz-deficient wackestones. The fossil assemblage is dominated by sponges and foraminifera, with bryozoans, echinoids, calcareous algae, bivalves and calcispheres occurring as accessory components The foraminifera are dominated by planktonic forms.

\section{BAIA 2}

Unit 1 is composed of fine-grained wackestone, with rare quartz. Among the fossils, foraminifera, sponges and calcareous algae (Dasycladaceae) dominate.

Units 2-4 are made up of packstone and, subordinately, wackestone. Within those rocks cross-bedding (in packstone) and laminations (in wackestone) are clearly visible. Within the horizon represented by the $B_{2} 11$ sample breccia is found; the clasts are analogous to the substrate, while the matrix is rich in quartz $(20 \%)$ of medium grain size (which amounts to the largest grain size in the Baia 2 section). The fossil assemblage contains calcareous algae (Dasycladaceae), foraminifera, sponges and echinoids. In more grain-rich intervals Dasycladaceae dominate.

Unit 5-7 are composed of wackestone, with interbedded layers composed of mudstone (Unit 6) and packstone (Unit 7). The quartz content is usually very low or absent; significant quartz percentages are noted only at the base of Unit 5 and in Unit 7. Among the fossils, foraminifera, sponges and calcareous algae (Dasycladaceae) dominate.
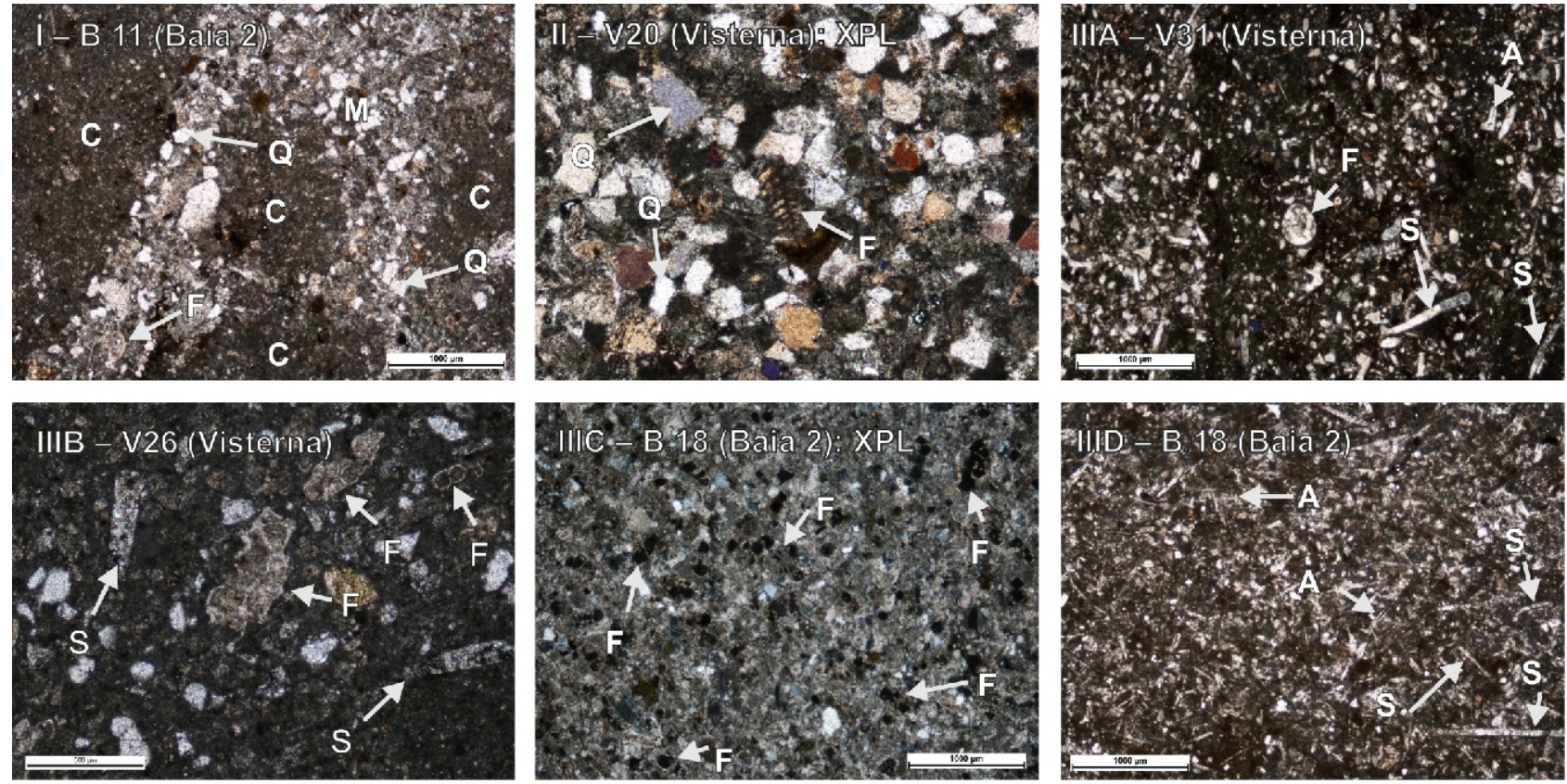

Fig. 9. Microfacies recognized in the sections studied

Numbers on photos correspond to microfacies types; thin-section photos, sample number given after microfacies number; XPL - cross polarized light; A - algae; C - clasts (breccia); F - foraminifera; M - matrix (breccia); Q - quartz; S - spiculites (sponges) 
Microfacies, detrital grain and fossil classifications from Visterna

\begin{tabular}{|c|c|c|c|c|c|c|c|c|c|c|c|c|c|c|c|c|c|c|c|}
\hline \multicolumn{20}{|c|}{ VISTERNA } \\
\hline \multirow[b]{2}{*}{$\begin{array}{r}\text { SAMPLE } \\
\text { NUMBER }\end{array}$} & \multicolumn{3}{|c|}{ CLASSIFICATION } & \multicolumn{5}{|c|}{ DETRITAL GRAINS } & \multicolumn{11}{|c|}{ FOSSILS } \\
\hline & Folk & Dunham & Microfacies & 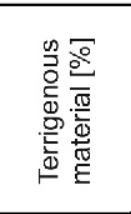 & 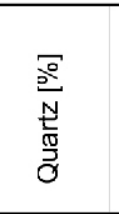 & $\begin{array}{l}\stackrel{0}{N} \\
\frac{N}{\infty} \\
. \frac{C}{\pi} \\
\mathbb{N}\end{array}$ & 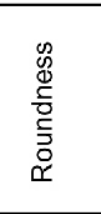 & $\begin{array}{l}\text { D } \\
\stackrel{E}{E} \\
\stackrel{0}{0}\end{array}$ & 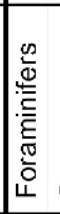 & 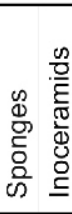 & 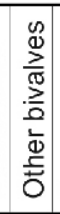 & \begin{tabular}{|c|} 
\\
0 \\
0 \\
0 \\
0 \\
0 \\
0 \\
0 \\
0 \\
0 \\
0
\end{tabular} & $\begin{array}{l}\mathrm{Cal} \\
0 \\
0 \\
\frac{\pi}{0} \\
\frac{\pi}{0} \\
\frac{\pi}{0} \\
\frac{1}{0} \\
\frac{\pi}{0}\end{array}$ & 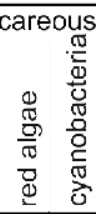 & 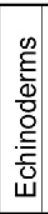 & \begin{tabular}{|l|}
$\frac{n}{0}$ \\
0 \\
.0 \\
$\frac{0}{0}$ \\
$\frac{0}{\pi}$ \\
$\overline{0}$ \\
\end{tabular} & $\begin{array}{l}0 \\
0 \\
0 \\
0 \\
\frac{0}{5} \\
0 \\
0\end{array}$ & 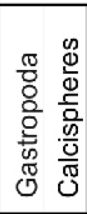 & 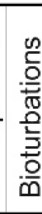 \\
\hline V1 & S.B. & W & IIIA & $40 \%$ & $10 \%$ & $-;-$ & $-;+1-$ & + & $\bullet$ & $\bullet \bullet$ & & $\bullet$ & & & & & & & $\bullet$ \\
\hline V2 & S.B. & W & $\mathrm{WLA}$ & $>50 \%$ & $20 \%$ & - & $-;+1-$ & + & $\bullet$ & $\bullet$ & & $\bullet$ & $\bullet$ & & $\bullet$ & & & $\bullet$ & \\
\hline V3 & P.B. & W/P & IIIA & $>50 \%$ & $20 \%$ & - & $-;+1-$ & + & $\bullet$ & $\bullet \bullet$ & & $\bullet$ & $\bullet$ & $\bullet$ & $\bullet$ & & & & $\bullet$ \\
\hline V4 & P.B. & W/P & IIIC & $>50 \%$ & $15-20 \%$ & - & $-;+1-$ & + & $\bullet$ & & & & $\bullet$ & & $\bullet$ & & $\bullet$ & & $\bullet$ \\
\hline V5 & P.B. & W/P & IIIA & $>50 \%$ & $5-10 \%$ & - & $-;+1-$ & $+1-$ & $\bullet$ & $\bullet$ & & $\bullet$ & $\bullet$ & & $\bullet$ & & & & $\bullet$ \\
\hline V6 & P.B. & W/P & IIIB & $50 \%$ & $10 \%$ & - & $-;+1-$ & + & $\bullet$ & $\bullet$ & & $\bullet$ & $\bullet$ & $\bullet$ & $\bullet$ & & & & $\bullet$ \\
\hline V7 & P.B. & W/P & IIIC & $>50 \%$ & $15 \%$ & - & $-;+1-$ & + & $\bullet$ & & $\bullet$ & $\bullet$ & & & $\bullet$ & & $\bullet$ & $\bullet$ & $\bullet$ \\
\hline V8 & P.B. & W/P & IIIC & $50 \%$ & $15 \%$ & - & $-;+1-$ & + & $\bullet$ & $\bullet \bullet$ & & & $\bullet$ & $\bullet$ & & & $\bullet$ & & $\bullet$ \\
\hline V9 & P.I. & $\mathrm{P}$ & II & $>50 \%$ & $15 \%$ & $+1-;-$ & $-;+1-$ & $+1-$ & 0 & & & & $\bullet$ & & & & & & \\
\hline V10 & P.I. & $P$ & II & $>50 \%$ & $20 \%$ & $+1-;-$ & $-;+1-$ & $+1-$ & 0 & & & 0 & 0 & & 0 & & & & \\
\hline V11 & P.I. & $\mathrm{P}$ & II & $50 \%$ & $25 \%$ & $+/-;-$ & $-;+1-$ & $+1-$ & $\circ$ & & & & 0 & & $\circ$ & & & & $\bullet$ \\
\hline V12 & P.I. & $\mathrm{P}$ & II & $>50 \%$ & $20-25 \%$ & $+1-;-$ & $-;+1-$ & $+1-$ & 0 & & & & & & 0 & & & & \\
\hline V13 & S.B. & $W$ & IIIC & $50 \%$ & $20-25 \%$ & - & $-;+1-$ & + & $\bullet$ & $\bullet \bullet$ & & & & & $\bullet$ & & & & $\bullet$ \\
\hline V14 & S.B. & $W$ & IIIB & $40-50 \%$ & $10 \%$ & - & $-;+1-$ & + & $\bullet$ & & & & $\bullet$ & & $\bullet$ & & & & $\bullet$ \\
\hline V15 & P.I. & $\mathrm{P}$ & II & $>50 \%$ & $15-20 \%$ & - & $-;+1-$ & $+1-$ & 0 & & & & 0 & & 0 & & & 0 & \\
\hline V16 & P.B. & W/P & IIIA & $50 \%$ & $15 \%$ & - & $-;+1-$ & $+1-$ & $\bullet$ & $\bullet$ & & & $\bullet$ & & & & & & $\bullet$ \\
\hline V17 & S.B. & $W$ & IIIC & $30 \%$ & $10 \%$ & - & $-;+1-$ & $+1-$ & $\bullet$ & & & & & $\bullet$ & & & & & $\bullet$ \\
\hline V18 & P.B. & $\mathrm{P}$ & IIID & $>50 \%$ & $10 \%$ & - & $-;+1-$ & + & $\bullet$ & & & & $\bullet$ & & $\bullet$ & & & & \\
\hline V18B & S.B. & W & III D/IIIA & $40-50 \%$ & $10 \%$ & - & $-;+1-$ & + & $\bullet$ & $\bullet \bullet$ & & & $\bullet$ & & & & & & $\bullet$ \\
\hline V19 & S.B. & W/P & IIIC & $40-50 \%$ & $15 \%$ & - & $-;+1-$ & + & $\bullet$ & $\bullet$ & & & $\bullet$ & & $\bullet$ & & & & $\bullet$ \\
\hline V20 & P.I. & $\mathrm{P}$ & II & $>50 \%$ & $20-30 \%$ & $+1-;-$ & $-;+1-$ & $+1-$ & $\bullet$ & & & & & & & & & & \\
\hline V21 & P.I. & $\mathrm{P}$ & II & $50 \%$ & $10-15 \%$ & - & $-;+1-$ & $+1-$ & & & & & 0 & & & & & & \\
\hline V23 & P.I. & W/P & IIIA & $50 \%$ & $10-15 \%$ & - & $-;+1-$ & + & $\bullet$ & $\bullet$ & & $\bullet$ & $\bullet$ & & $\bullet$ & & & & $\bullet$ \\
\hline V24 & S.B. & $W$ & IIIA & $50 \%$ & $5 \%$ & - & $-;+1-$ & + & $\bullet$ & $\bullet$ & & & $\bullet$ & & & & & & $\bullet$ \\
\hline V25 & P.I. & $\mathrm{P}$ & II & $>50 \%$ & $30 \%$ & $+/-;+$ & - & - & $\bullet$ & & & & $\bullet$ & $\bullet$ & & & & & \\
\hline V26 & S.B. & $W$ & IIIB & $40-50 \%$ & $15 \%$ & - & $-;+1-$ & + & $\bullet$ & $\bullet$ & & & & $\bullet$ & $\bullet$ & & & & $\bullet$ \\
\hline V27 & S.B. & $W$ & IIIB & $40-50 \%$ & $15 \%$ & - & $-;+1-$ & + & $\bullet$ & $\bullet$ & & & & $\bullet$ & $\bullet$ & & & & $\bullet$ \\
\hline V28 & S.B. & $W$ & IIIB & $40-50 \%$ & $5 \%$ & - & $-;+1-$ & + & $\bullet$ & $\bullet$ & & & & & & & $\bullet$ & & $\bullet$ \\
\hline V29 & S.B. & $W$ & IIIC & $30-35 \%$ & $1-5 \%$ & $-;-$ & $-;+1-$ & + & $\bullet$ & $\bullet$ & & & & & & & & & $\bullet$ \\
\hline V30 & P.B. & $\mathrm{P}$ & IIIB & $>50 \%$ & $15-20 \%$ & $-;+1-$ & $-;+1-$ & $+1-$ & $\bullet$ & & & & $\bullet$ & & $\bullet$ & $\bullet$ & & & \\
\hline V31 & S.B. & W & IIIA & $30-40 \%$ & $1-5 \%$ & - & $-;+1-$ & + & $\bullet$ & $\bullet$ & & & $\bullet$ & & & & & & \\
\hline V31A & S.B. & $W$ & IIIB & $30-40 \%$ & $1-5 \%$ & $-;-$ & $-;+1-$ & + & $\bullet$ & $\bullet$ & & & $\bullet$ & & & & & & $\bullet$ \\
\hline V31B & S.B. & $W$ & IIIB & $20-30 \%$ & $1-5 \%$ & $-;-$ & $-;+1-$ & + & $\bullet$ & $\bullet$ & & & & & & & & & \\
\hline V32 & S.B. & W/P & IIIA & $40-50 \%$ & $15-20 \%$ & - & $-;+1-$ & + & • & $\bullet$ & & - & $\bullet$ & & $\bullet$ & - & $\bullet$ & $\bullet$ & $\bullet$ \\
\hline
\end{tabular}

S.B. - sparse biomicrite; P.B. - packed biomicrite; P.I. - packed intramicrite; W. - wackestone; P. - packstone; grain size: $(-)$ very small; $(-)$ small; (+/-) medium; (+) big; roundness: (-) angular; (+/-) poorly rounded; sorting: (+/-) moderately sorted; (+) well sorted; dots: abundant; circles: poorly 
Microfacies, detrital grains and fossils classification from Baia 2

\begin{tabular}{|c|c|c|c|c|c|c|c|c|c|c|c|c|c|c|c|c|}
\hline & & & & & BAIA 2 & & & & & & & & & & & \\
\hline & CLA & IFICA & ION & & DETRITA & L GRA & INS & & & & & & ES: & SILS & & \\
\hline $\begin{array}{l}\text { SAMPLE } \\
\text { NUMBER }\end{array}$ & Folk & $\begin{array}{l}\frac{E}{\mathbb{I}} \\
\stackrel{5}{5} \\
0\end{array}$ & $\begin{array}{l}\frac{\mathscr{c}}{\frac{0}{0}} \\
\frac{\pi}{\pi} \\
\frac{0}{0} \\
\frac{0}{2}\end{array}$ & 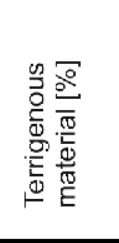 & $\begin{array}{l}\frac{a}{0} \\
\frac{N}{0} \\
\frac{0}{0}\end{array}$ & $\begin{array}{l}\frac{N}{N} \\
\frac{N}{\omega} \\
\frac{5}{\mathbb{N}} \\
0\end{array}$ & 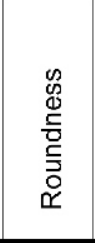 & $\begin{array}{l}\text { D. } \\
\stackrel{.}{ \pm} \\
\text { Dे } \\
\text { c) }\end{array}$ & 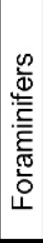 & 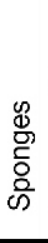 & 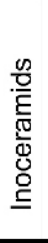 & $\begin{array}{l}\frac{8}{2} \\
\frac{2}{10} \\
\frac{2}{0} \\
\frac{5}{0}\end{array}$ & 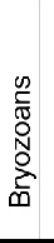 & 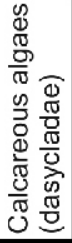 & 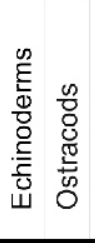 & 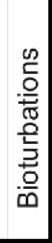 \\
\hline $\mathrm{B}_{2} 1$ & S.B. & $W$ & $\mathrm{IIIB}$ & $15-20 \%$ & $1-5 \%$ & $-;-$ & $-;+1-$ & + & $\bullet$ & $\bullet$ & & & & $\bullet$ & & \\
\hline $\mathrm{B}_{2} 2$ & S.B. & $W$ & IIIB & $30-40 \%$ & $5-10 \%$ & - & $-;+1-$ & + & $\bullet$ & $\bullet$ & & & & $\bullet$ & & \\
\hline $\mathrm{B}_{2} 3$ & S.B. & $W$ & IIIA & $30-40 \%$ & $1 \%$ & - & $-;+1-$ & + & $\bullet$ & $\bullet$ & & & & $\bullet$ & $\bullet$ & $\bullet$ \\
\hline $\mathrm{B}_{2} 4$ & S.B. & $W$ & IIIA & $40-50 \%$ & $1-5 \%$ & - & $-;+1-$ & + & $\bullet$ & $\bullet$ & & & & - & & \\
\hline $\mathrm{B}_{2} 5$ & S.B. & $W$ & IIIB & $15 \%$ & 0 & -;- & $-;+1-$ & + & $\bullet$ & $\bullet$ & & & & $\bullet$ & & $\bullet$ \\
\hline $\mathrm{B}_{2} 6$ & S.B. & $W$ & IIID & $15-20 \%$ & 0 & $-;-$ & $-;+1-$ & + & $\bullet$ & $\bullet$ & & & & $\bullet$ & & \\
\hline $\mathrm{B}_{2} 7$ & S.B. & $W$ & IIIB & $20 \%$ & $5-10 \%$ & $-;-$ & $-;+1-$ & + & $\bullet$ & $\bullet$ & & & & $\bullet$ & $\bullet$ & $\bullet$ \\
\hline $\mathrm{B}_{2} 7 \mathrm{~A}$ & S.B. & $W$ & $\mathrm{IIIB}$ & $10-15 \%$ & $1 \%$ & $-;-$ & $-;+1-$ & + & $\bullet$ & $\bullet$ & & & & $\bullet$ & $\bullet$ & \\
\hline $\mathrm{B}_{2} 8$ & P.B. & $\mathrm{P}$ & IIID & $>50 \%$ & $10-15 \%$ & - & $-;+1-$ & + & $\bullet$ & $\bullet$ & & - & & $\bullet$ & & \\
\hline $\mathrm{B}_{2} 9$ & S.I.IP.I. & $M / P$ & II & $30 \%$ & $5-10 \%$ & - & $-;+1-$ & + & & 0 & & & & 0 & & \\
\hline $\mathrm{B}_{2} 10$ & S.B & $W$ & IIIB & $15 \%$ & $1 \%$ & - & $-;+1-$ & + & - & $\bullet$ & & & & $\bullet$ & & \\
\hline $\mathrm{B}_{2} 11(\mathrm{C})$ & S.B. & W & 1 & $10 \%$ & $5 \%$ & - :- & $-;+1-$ & + & - & - & - & - & - & - & $-\quad-$ & - \\
\hline $\mathrm{B}_{2} 11(\mathrm{M})$ & P.B. & $\mathrm{P}$ & 1 & $>50 \%$ & $20 \%$ & $+1-;-$ & $-;+1$ & $+1-$ & $\bullet$ & $\bullet$ & $\bullet$ & & $\bullet$ & $\bullet$ & - $\bullet$ & \\
\hline $\mathrm{B}_{2} 12$ & P.B. & $\mathrm{P}$ & IIID & $>50 \%$ & $15 \%$ & - & $-;+1-$ & + & & $\bullet$ & & & & $\bullet$ & & \\
\hline $\mathrm{B}_{2} 12^{\prime \prime}$ & S.B. & W/P & IIID & $50 \%$ & $0-1 \%$ & - & $-;+1-$ & + & - & $\bullet$ & & & & $\bullet$ & & \\
\hline $\mathrm{B}_{2} 13 "$ & S.B. & $W$ & IIIA & $30-40 \%$ & $10-15 \%$ & - & $-;+1-$ & + & $\bullet$ & $\bullet$ & & & & $\bullet$ & & \\
\hline $\mathrm{B}_{2} 13$ & S.B. & $W$ & IIIA & $15-20 \%$ & $0-1 \%$ & -; - & $-;+1-$ & + & $\bullet$ & $\bullet$ & & & & $\bullet$ & & $\bullet$ \\
\hline $\mathrm{B}_{2} 14$ & S.B. & $W$ & IIIB & $15 \%$ & $0-1 \%$ & $-;-$ & $-;+1-$ & + & $\bullet$ & $\bullet$ & & & & $\bullet$ & & $\bullet$ \\
\hline $\mathrm{B}_{2} 15$ & S.B & $W$ & IIIB & $15-20 \%$ & $0-1 \%$ & -; - & $-;+1-$ & + & $\bullet$ & $\bullet$ & & & & $\bullet$ & & \\
\hline $\mathrm{B}_{2} 16$ & S.B. & $W$ & IIIB & $15-20 \%$ & $0-1 \%$ & -;- & $-;+1-$ & + & $\bullet$ & $\bullet$ & & & & $\bullet$ & & \\
\hline $\mathrm{B}_{2} 17$ & S.I. & $\mathrm{M}$ & II & $5-10 \%$ & $0 \%$ & $-;-$ & $-;+1-$ & + & & & & & & & & \\
\hline $\mathrm{B}_{2} 18$ & P.B. & $\mathrm{P}$ & IIIC & $>50 \%$ & $15 \%$ & - & - & + & $\bullet$ & $\bullet$ & & - & - & • & & \\
\hline
\end{tabular}

S.I. - sparse intramicrite; M. - mudstone; $B_{2} 11(C)$ - clasts; $B_{2} 11(M)$ - matrix; other explanations as in Table 1

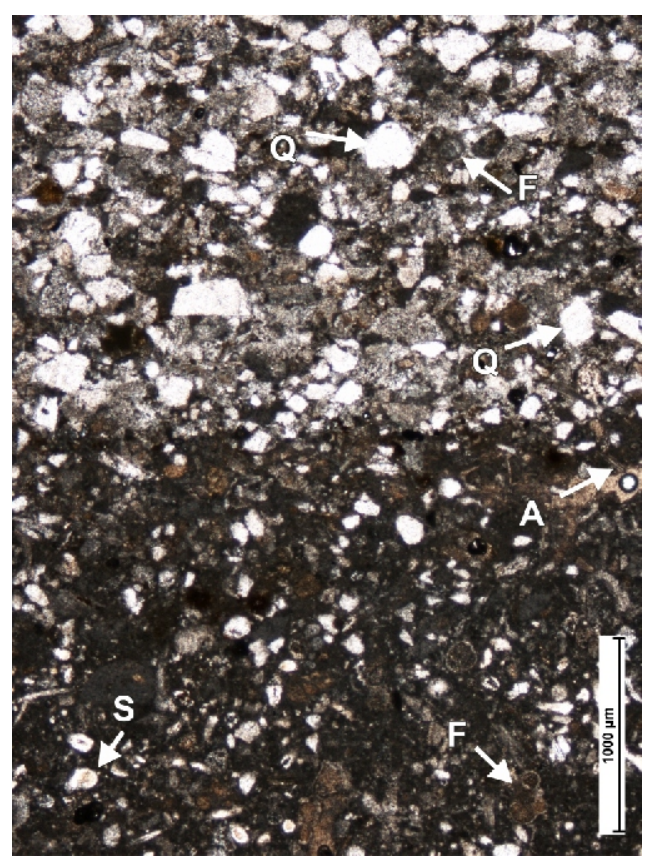

\section{INTEGRATED BIOSTRATRIGRAPHY}

UPPER TURONIAN

The Upper Turonian is documented in the Visterna section. The basal part of the succession (Unit 1) yielded Inoceramus ex gr. lamarcki Parkinson, 1818, Mytiloides striatoconcentricus (Gümbel, 1868) and Inoceramus perplexus Whitfield, 1877. This assemblage is indicative of the lower part of the Upper Turonian (e.g., Ernst et al., 1983; Walaszczyk and Cobban, 2000; Kennedy and Gale, 2015; Dochev, 2015; Walaszczyk et al., 2016b). The assemblage also yielded Inoceramus ex gr. inaequivalvis Schlüter, 1877, a group spanning the upper Middle and lower Upper Turonian (and ranging higher within the Upper Turonian; Tröger, 1989; Walaszczyk and Cobban,

Fig. 10. Erosive boundary in the Visterna section between layers V24 (down) and V25 (up)

Thin section photo; explanations as in Figure 9 
2000). Ammonites of the genus Lewesiceras (Fig. 18C, D), co-occurring with the inoceramid assemblage and spanning the entire Visterna succession, are typical of the Turonian.

The Visterna section yielded a taxonomically variable foraminiferal assemblage. The topmost part of Unit 1 yielded Helvetoglobotruncana helvetica (Bolli, 1945), the marker of the eponymous taxon-range zone (Walaszczyk and Peryt, 1998; Dubicka and Peryt, 2012). Based on inoceramid data in the Visterna section, $H$. helvetica, usually thought to go extinct at the Middle-Late Turonian boundary (Ogg and Hinnov, 2012; Ogg et al., 2016), survived here into at least the early Late Turonian. This confirms the previous early Late Turonian reports of the species from the Vistula River section (Walaszczyk and Peryt, 1998), western Ukraine (Dubicka and Peryt, 2012) and other parts of western Tethys (see Huber and Petrizzo, 2014). [It is worth observing that Szász and lon (1988) reported $H$. helvetica from even younger strata of the Babadag Basin (from the Lower Coniacian). However, these findings are not confirmed in our study].

Helvetoglobotruncana helvetica is accompanied by several benthic genera - Ammodiscus, Arenobulimina, Lenticulina, Textularia, and Miliolina - and by a variety of planktonic foraminifera species: Hedbergella delrioensis (Carsey, 1926), Helvetoglobotruncana praehelvetica (Trujillo, 1960), Heterohelix cf. reussi Cushman, 1938, Marginotruncana coronata (Bolli, 1945), M. marginata (Reuss, 1845), M. pseudolinneiana Pessagno, 1967, M. schneegansi (Sigal, 1952), Whiteinella baltica Douglas and Rankin, 1969 and W. brittonensis (Loeblich and Tappan, 1961; Figs. 11, 13 and 14).

Units 2-10 yielded Arenobulimina sp., Dicarinella cf. imbricata (Mornod, 1949), Eponides sp., Hedbergella delrioensis (Carsey, 1926), Marginotruncana cf. coldreriensis (Gandolfi, 1957), M. marginata (Reuss, 1845), M. cf. marianosi (Douglas, 1969), M. pseudolinneiana Pessagno, 1967, M. schneegansi (Sigal, 1952), M. tarfayaensis (Lehmann, 1963), Orbignyna sp., Textularia sp., Whiteinella baltica Douglas and Rankin, 1969 and W. brittonensis (Loeblich and Tappan, 1961). This assemblage allows this portion of the Visterna succession to be dated to the Marginotruncana coronata/Marginotruncana schneegansi Zone (Ogg and Hinnov, 2012; Ogg et al., 2016), which places the interval into the Upper Turonian (Figs. 11, 13 and 14).

Foraminiferal abundances vary in the Visterna succession, from quite sparse (e.g., units 8 and 10) to very abundant (e.g., units 1, 2, and 4; see Table 3). Planktonic / benthic foraminifera ratios were calculated (see Table 3 and "Environmental interpretation" chapter).

\section{LOWER CONIACIAN}

The Lower Coniacian is well-documented in the Caugagia section, with two inoceramid zonal markers: Cremnoceramus deformis erectus (Meek, 1877) and C. deformis deformis (Meek, 1871). The first occurrence of the former marks the base of the Coniacian (Kauffman et al., 1996; Walaszczyk and Woods, 1998; Walaszczyk et al., 2010). The latter species characterizes the higher portion of the substage, but not the highest extent (Walaszczyk and Wood, 1998, 2018). The available part of the succession spans the lower and middle parts of the Lower Coniacian. Previous reports of Szász (1985) suggest that the succession ranges down into the uppermost Turonian; however, this portion of the section is no longer exposed.

\section{MIDDLE CONIACIAN}

The Middle Coniacian was recognized in the Baia 2 section. While the inoceramids and ammonites collected are poorly pre- served, the assemblage - composed of Platyceramus mantelli (de Mercey; Barrois 1879), Mesopuzosia sp, Nowakites sp., Peroniceras sp., Peroniceras tridorsatum (Schlüter, 1867) and Scaphites ex gr. fisheri Riedel, 1931 - does demonstrate the Middle Coniacian age of the succession studied.

The foraminiferal assemblage from the Baia 2 section is composed of Archaeoglobigerina cf. blowi Pessagno, 1967, A. cf. bosquensis Pessagno, 1967, Globigerinelloides sp., Heterohelix cf. reussi Cushman, 1938, Lenticulina sp., Marginotruncana cf. coldreriensis Gandolfi, 1957, M. coronata (Bolli, 1945), M. cf. marginata (Reuss, 1845), M. pseudolinneiana Pessagno, 1967, Textularia sp. and Whiteinella baltica Douglas and Rankin, 1960 (see Figs. 12 and 14). This assemblage is indicative of the Coniacian Marginotruncana sinuosa Zone (Dubicka and Peryt, 2012) and/or the Dicarinella concavata Zone (Ogg and Hinnov, 2012; Ogg et al., 2016). Only 78 foraminifera were recovered from the Baia 2 section; such a low number does not allow for the calculation of reliable P/B (planktonic/benthic foraminifera) ratios.

\section{REMARKS ON INOCERAMIDS AND AMMONITES}

Both inoceramids and ammonites occur in the entire succession. Inoceramids are most common in the basal part of the Upper Turonian and - in particular - in the Lower Coniacian. It is this interval (and area) where most of the material described by Szász (1985) orginates. Indeed, it is so far one of the richest Early Coniacian inoceramid assemblage known from the entire Euramerican biogeographic region. Unfortunately, the details of their record in the younger strata of this succession are unknown, due to the poor state of the exposure. Ammonites were found in the Turonian and Middle Coniacian; no ammonites were recovered from the Lower Coniacian.

\section{INOCERAMIDS}

Inoceramus perplexus Whitfield, 1877; Figure 15A, A', B, B'; represented by 6 poorly preserved, incomplete specimens; the other 6 specimens are referred to here as cf. perplexus (MWGUW Zl/87/029-040). All are from the lower part of the Visterna section. The material corresponds well to the diagnosis given by Walaszczyk and Cobban (2000). This species is known from the lower Upper Turonian of the Euramerican biogeographical province. Some forms are referred to as Inoceramus aff. perplexus (Fig. 15C, C', D, D').

Inoceramus lamarcki Parkinson, 1818 group; Figure 15E, F; three incomplete specimens (MWGUW Zl/87/049-051), relatively well-preserved, from the lower part of the Visterna section. The illustrated one is $57 \mathrm{~mm}$ long. Our specimens are the first true lamarcki representatives from Romania; most of the forms referred hitherto to this group and dated as Early Coniacian in Romania are Tethyoceramus. The group has a pandemic distribution.

Inoceramus inaequivalvis Schlüter, 1887; Figure 16A; three poorly preserved specimens from the lower part of the Visterna section (MWGUW ZI/87/052). The true range of the species is unknown, although commonly quoted as late Middle to early Late Turonian. The group of inaequivalvis is known from the entire Euramerican biogeographic region, and probably also from other biogeographic regions as well.

Mytiloides cf. striatoconcentricus (Gümbel, 1868); Figure $16 \mathrm{~B}, \mathrm{C}$; two single valve moulds from the lower part of the Visterna section (MWGUW Zl/87/053-054). This species first appears a short distance above the base of the Upper Turonian (Ernst et al., 1983), and dominates in the middle part of the 

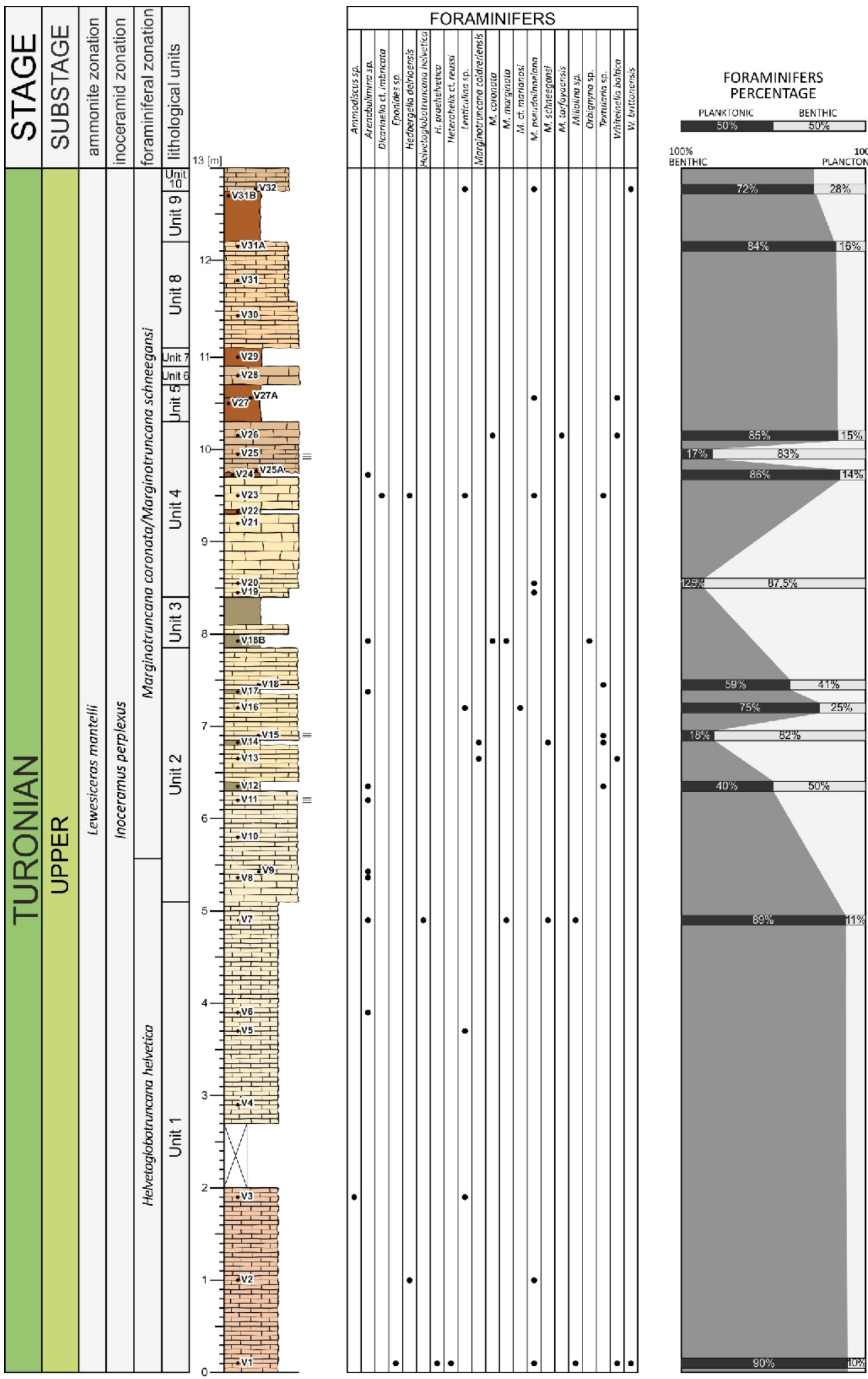

BENTHIC
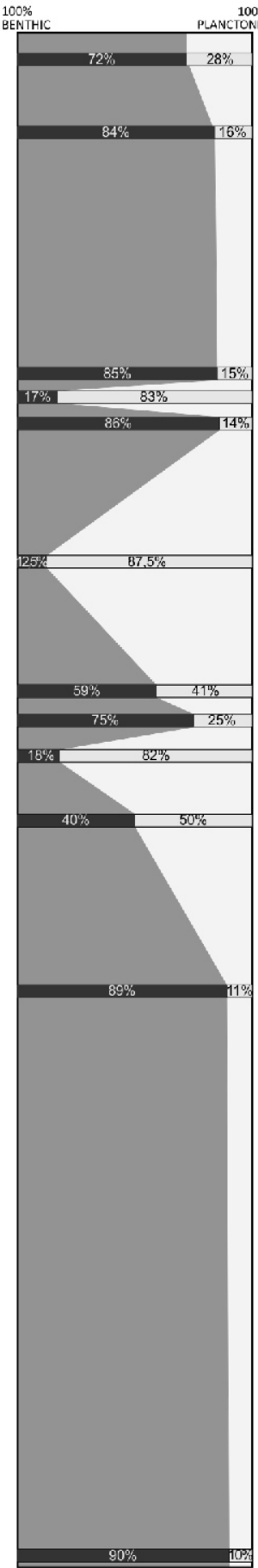

Fig. 11. Vertical distribution and planktonic/benthic (P/B) ratios of foraminifera in the Visterna section (Upper Turonian)

Explanation as in Figure 5 


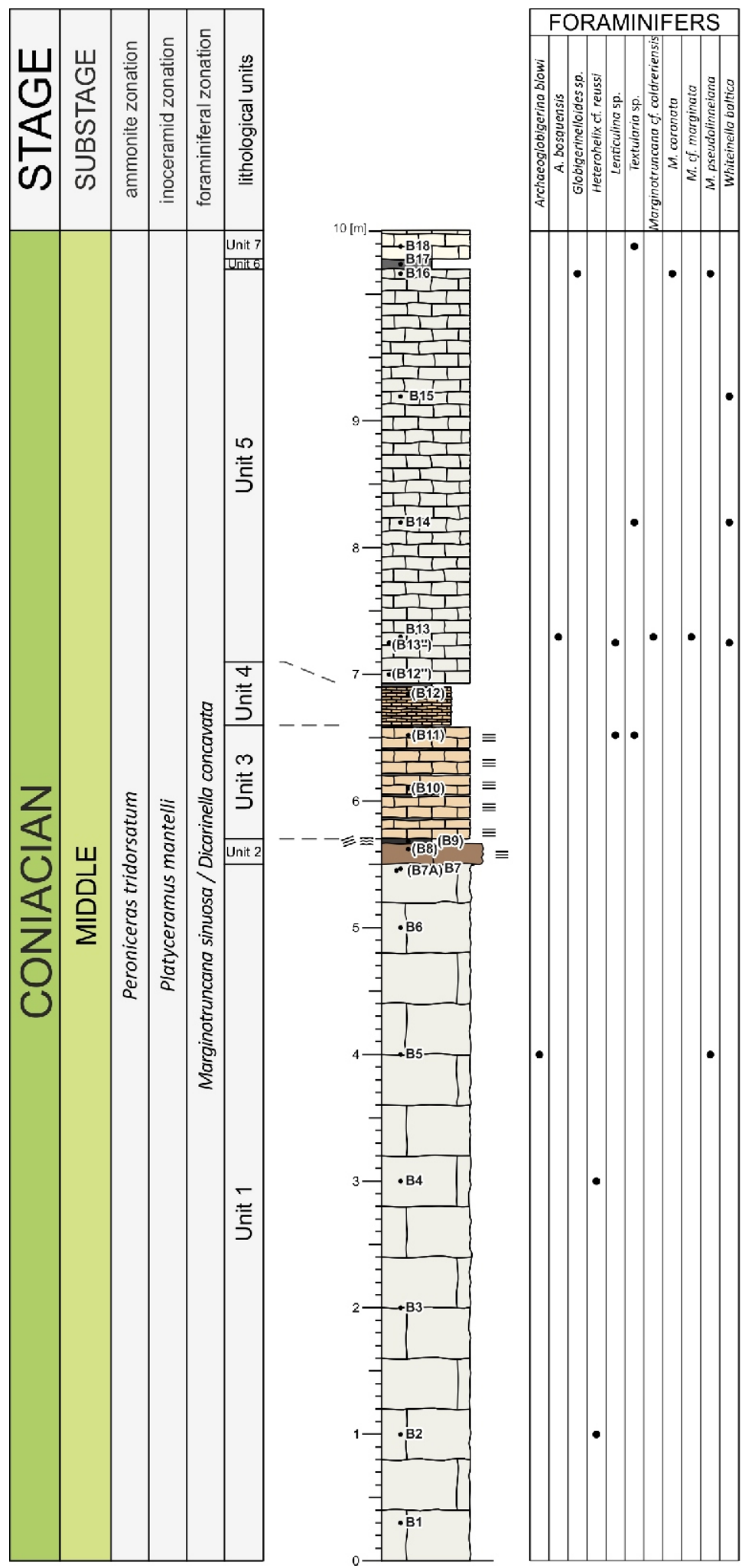

Fig. 12. Vertical distribution in foraminifera in the Baia 2 section (Middle Coniacian)

Explanation as in Figures 5 and 8 


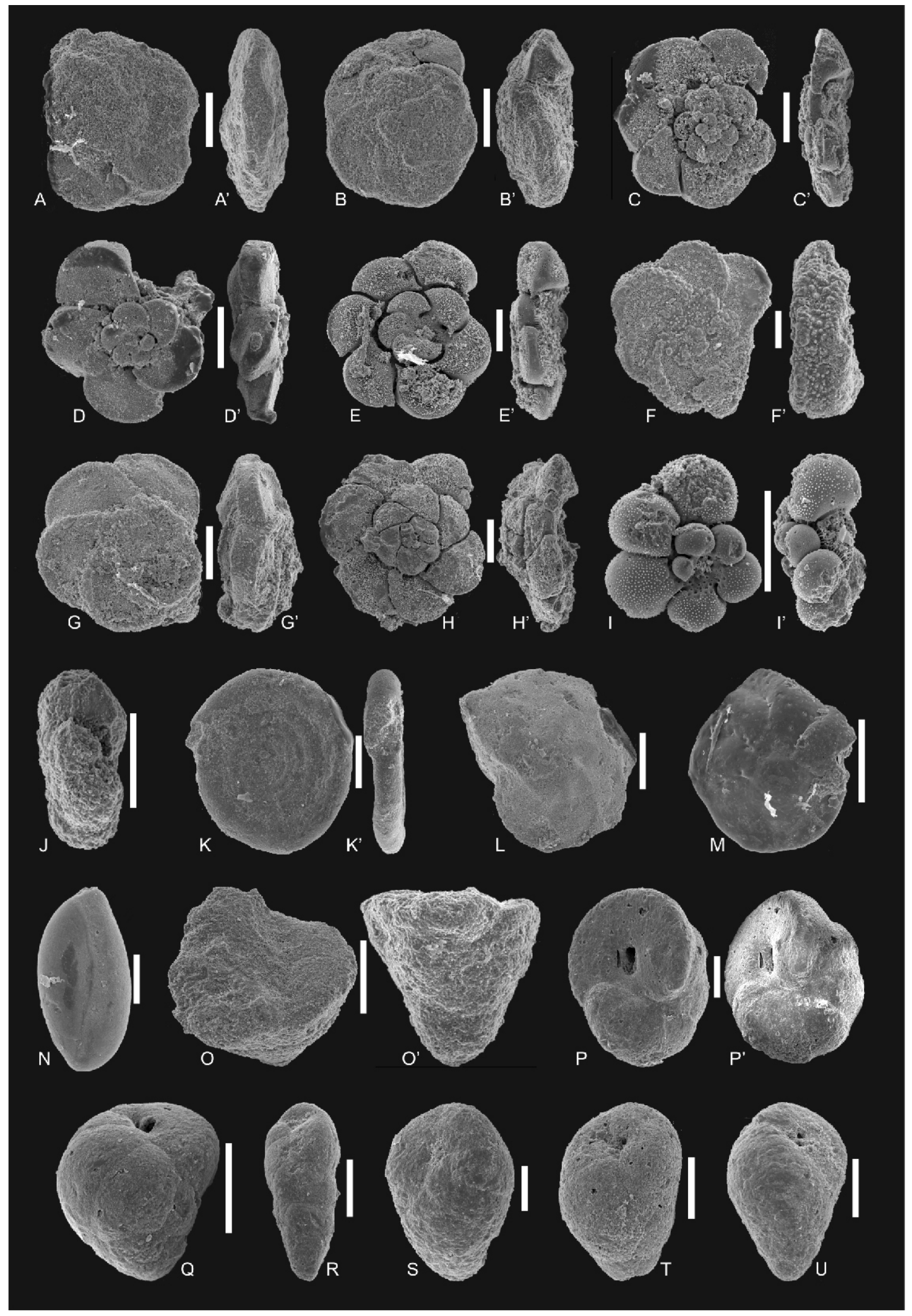

Fig. 13. Upper Turonian and Middle Coniacian foraminifera from the Babadag Basin

A, B - Marginotruncana cf. coldreriensis (Gandolfi, 1957), MWGUW ZI/67/49.Vra: 12 (V13), 14 (V14); C - Marginotruncana coronata (Bolli, 1945), MWGUW ZI/67/49.Vra20 (V18B); D-G - Marginotruncana pseudolinneiana Pessagno, 1967, MWGUW ZI/67/49.Vra: 1 (V2), 22 (V20), 23 (V23), 33 (V27A); H - Marginotruncana marginata (Reuss, 1845), MWGUW ZI/67/49.Vra31 (V27A); I - Whiteinella baltica Douglas and Rankin, 1969, MWGUW ZI/67/49.Vra34 (V18B); J - Hedbergella delrioensis (Carsey, 1926), MWGUW ZI/67/49.Vra24 (V23); K Ammodiscus sp., MWGUW ZI/67/49.Vra02 (V3); L - Lenticulina sp., MWGUW ZI/67/49.Vra03 (V3); M - Eponides sp., MWGUW ZI/67/49.Vra05 (V1); N - Miliolina sp., MWGUW ZI/67/49.Vra07 (V1); O - Textularia sp., MWGUW ZI/67/49.Vra15 (V14); P - Orbignyna sp., MWGUW ZI/67/49.Vra18 (V18B); Q-U - Arenobulimina sp., MWGUW ZI/67/49.Vra: 13 (V7), 16 (V12), 17 (V17), 19 (V18B), 28 (V24), MWGUW ZI/67/49; VraXX - museum numbers; (VXX) - sample number; SEM; scale bar - $200 \mu \mathrm{m}$ 

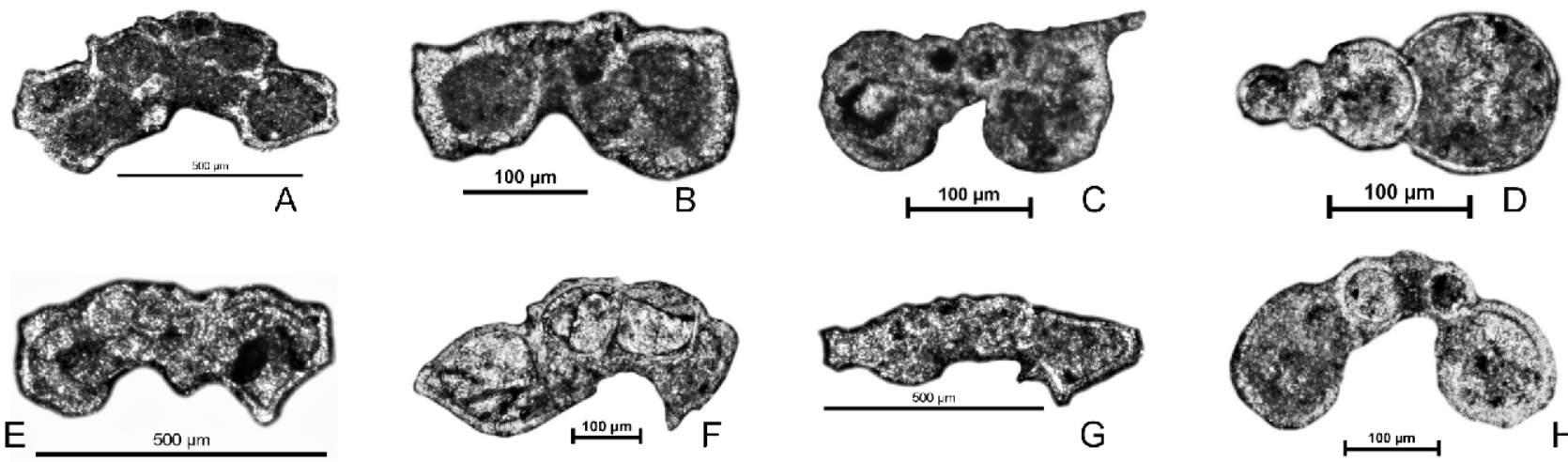

G
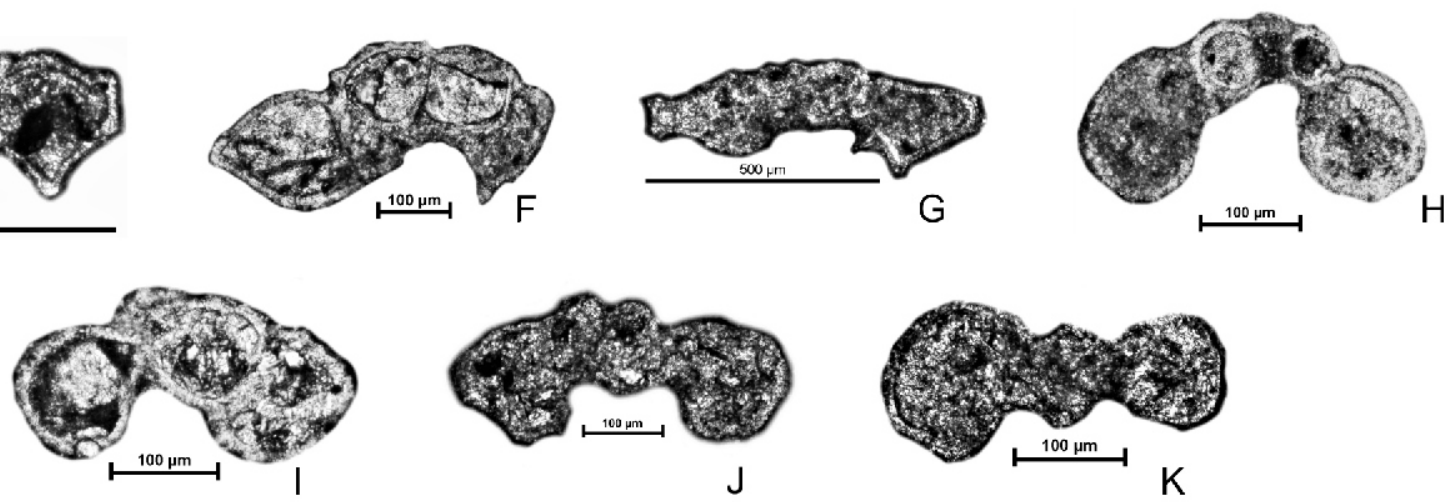

$\mathrm{K}$

Fig. 14. Upper Turonian and Middle Coniacian foraminifera from the Babadag Basin

A - Dicarinella cf. imbricata (Mornod, 1949), V23; B - Helvetoglobotruncana praehelvetica (Trujillo, 1960), V1; C - Helvetoglobotruncana helvetica (Bolli, 1945), V7; D - Heterohelix cf. reussi Cushman, 1938, V1; E - Marginotruncana cf. marianosi (Douglas, 1969), V16; F Marginotruncana schneegansi (Sigal, 1952), V14; G - Marginotruncana tarfayaensis (Lehmann, 1963), V26; H - Whiteinella brittonensis (Loeblich and Tappan, 1961), V1; I - Archaeoglobigerina cf. blowi Pessagno, 1967, B25; J - Archaeoglobigerina cf. bosquensis Pessagno, 1967, B213; K - Globigerinelloides sp., B216; (VXX, B2YY) - sample number

Ta ble 3

Foraminiferal abundance and P/B (planktonic/benthic form ratio) in selected samples of the Visterna section

\begin{tabular}{|c|r|c|c|}
\hline \multirow{2}{*}{$\begin{array}{c}\text { Sample } \\
\text { number }\end{array}$} & \multicolumn{2}{|c|}{ Foraminifers } & \multirow{2}{*}{ P/B } \\
\cline { 2 - 3 } & Planctonic & Benthic & \\
\hline V1 & 205 & 22 & 9.32 \\
\hline V7 & 359 & 45 & 7.98 \\
\hline V12 & 15 & 15 & 1.00 \\
\hline V15 & 8 & 37 & 0.22 \\
\hline V16 & 86 & 28 & 3.07 \\
\hline V18 & 32 & 22 & 1.45 \\
\hline V20 & 4 & 28 & 0.14 \\
\hline V24 & 36 & 6 & 6.00 \\
\hline V25 & 2 & 10 & 0.20 \\
\hline V26 & 89 & 16 & 5.56 \\
\hline V31A & 26 & 5 & 5.20 \\
\hline V32 & 65 & 25 & 2.60 \\
\hline
\end{tabular}

substage. It has been reported from all over the Euramerican biogeographic region.

Cremnoceramus deformis erectus (Meek, 1877); Figure $16 \mathrm{~F}, \mathrm{G}$; four single valve moulds, moderately well-preserved specimens from the lower part of the Caugagia section (C1) (MWGUW ZI/87/055-058). This species constitutes the primary marker of the base of the Coniacian, and is well-represented in the Caugagia section.

Cremnoceramus deformis deformis (Meek, 1871); Figure 16D, E; two moderately well preserved specimens from the higher part of the Caugagia section (C2) (MWGUW $\mathrm{ZI} / 87 / 059-060)$. Specimens preserved as a moulds of one of the valves, shelly material is rare. Szász (1985) described a number of new species of the genus Cremnoceramus from Babadag; the revision of his material is in progress (by Walaszczyk and Gradinaru).

Platyceramus ex gr. mantelli (de Mercey; Barrois, 1879); Figure 17A-C; three moulds of single valves from the Baia 2 section (MWGUW ZI/87/061-063). The group was reported from the Middle and Upper Coniacian of Romania (Szász, 1985; Szász and Ion, 1988; Damian and Lazăr, 2005). The presence of the mantelli group and the absence of representatives of the genus Magadiceramus suggests a Middle Coniacian age (e.g., Walaszczyk and Cobban, 2006). However, it cannot be excluded, that $M$. subquadratus is absent due to environmental conditions.

\section{AMMONITES}

Ammonites are generally rare in the succession studied, although they dominate the macrofossil record in the Baia 2 section. Determination of the specimens collected was difficult due to poor preservation. Most of the material is left in open nomenclature.

The genus Nowakites (Fig. 19C, D), known from the Coniacian-Santonian of Europe (Germany, Spain, Austria, Sweden) Caucasus (Armenia), Asia (Japan, South India), Madagascar, and North America (Texas; Kennedy et al., 1995), occurs in the Middle Coniacian in the Baia 2 section.

Scaphites ex gr. fisheri (Fig. 18B) is reported from North Dobrogea for the first time. It was found in the Middle Coniacian of the Baia section - which is of considerably interest, given that previously S. fisheri has been only reported from the Lower Santonian-Lower Campanian (Kennedy and Christensen, 1991; Remin, 2010). Mesopuzosia (Fig. 18A) is a Turonian-Co- 


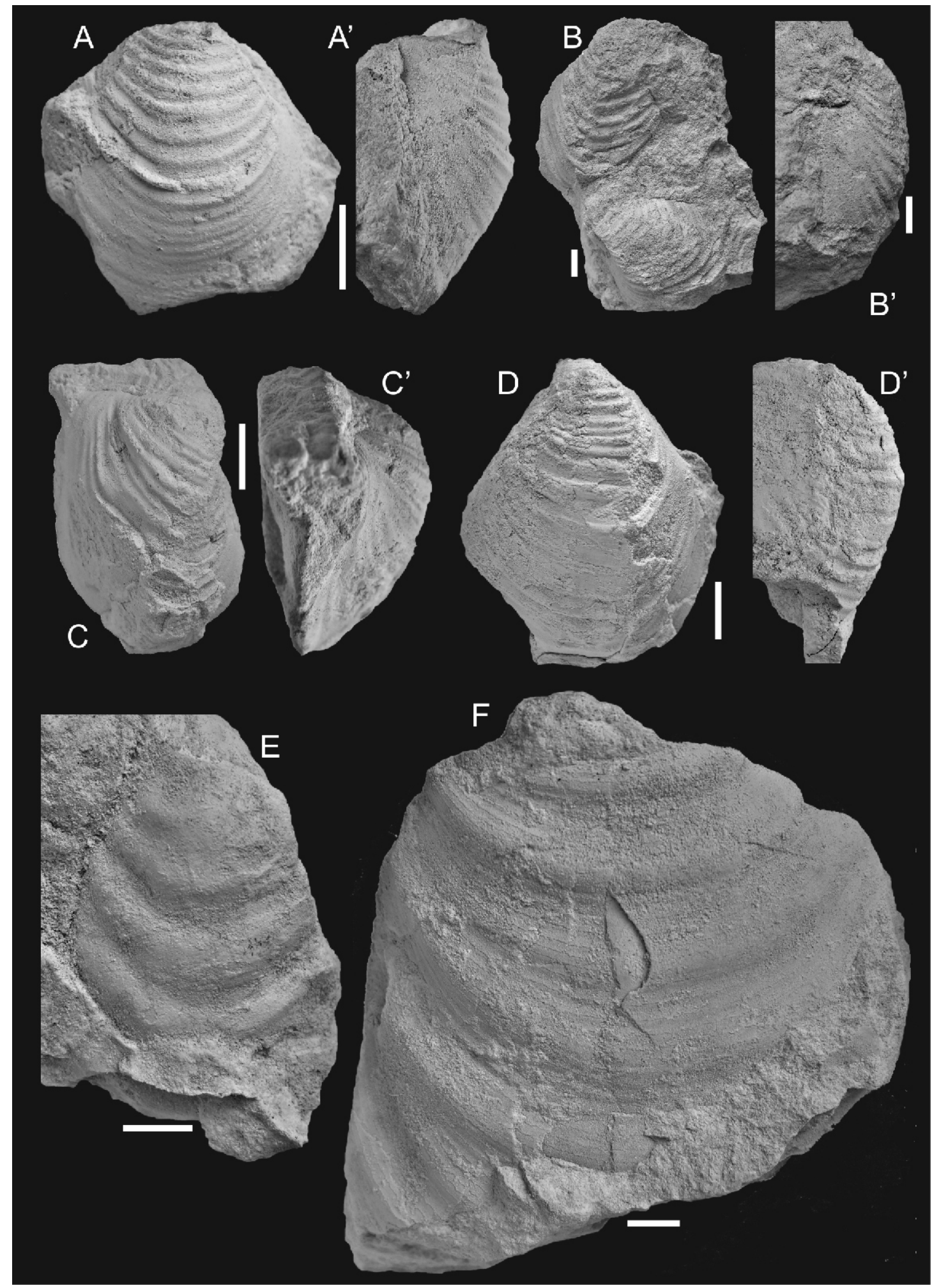

Fig. 15. Upper Turonian inoceramids of the Babadag Basin

A, B - Inoceramus perplexus Whitfield, 1877, MWGUW ZI/87/029-40; C, D - Inoceramus aff. perplexus Whitfield, 1877; MWGUW ZI/87/041-042; E, F - Inoceramus lamarcki Parkinson, 1818 group, MWGUW ZI/87/049-050; scale bar - $1 \mathrm{~cm}$; MWGUW ZI/87/XX - museum numbers 


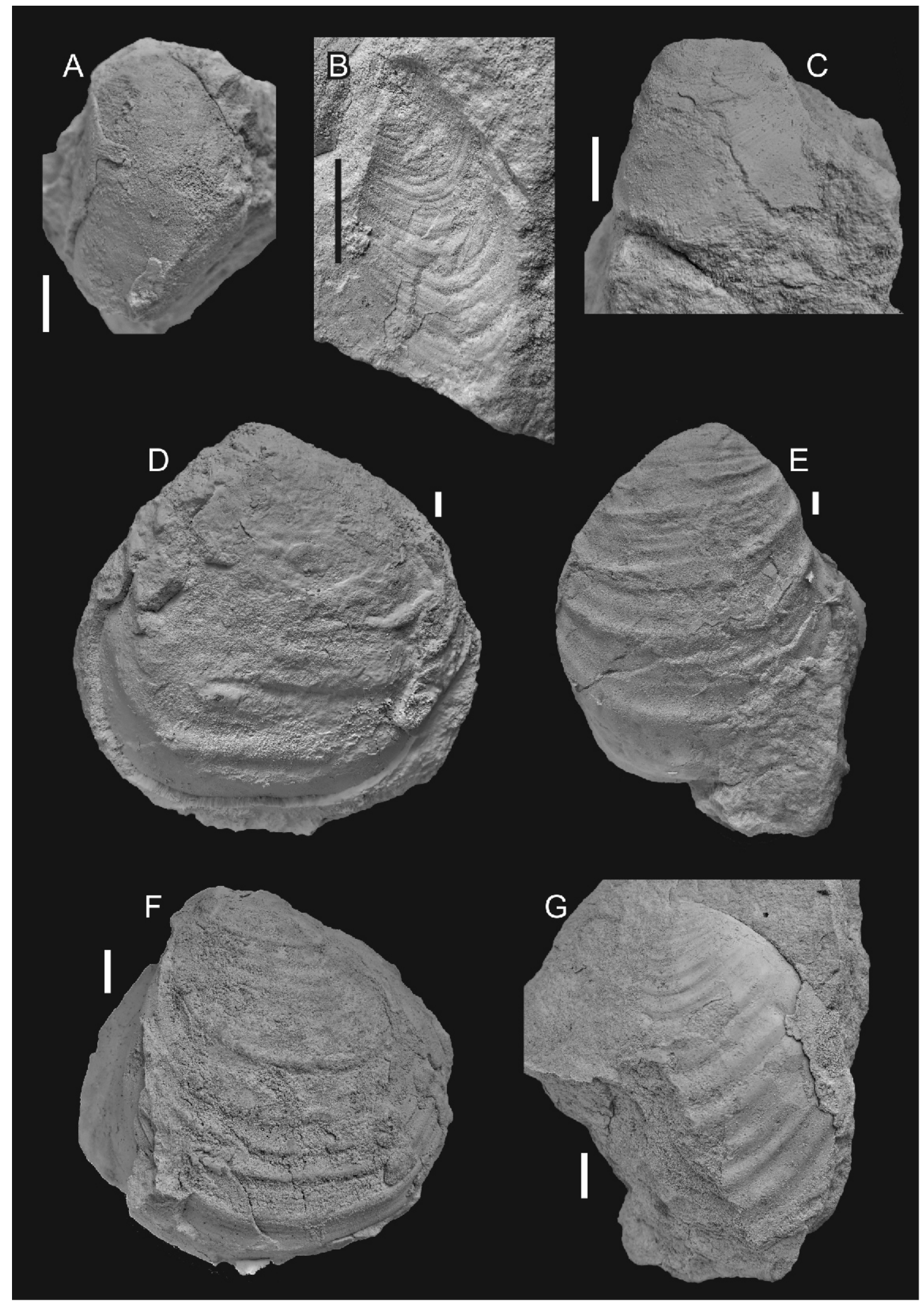

Fig. 16. Upper Turonian and Lower Coniacian inoceramids of the Babadag Basin

A - Inoceramus inaequivalvis Schlüter, 1887, MWGUW ZI/87/052; B, C - Mytiloides cf. striatoconcentricus (Gümbel, 1868), MWGUW ZI/87/053-054; D, E - Cremnoceramus deformis deformis (Meek, 1871), MWGUW ZI/87/059-060; F, G - Cremnoceramus deformis erectus (Meek, 1877), MWGUW ZI/87/055-056; scale bar - $1 \mathrm{~cm}$; MWGUW ZI/87/XX - museum numbers 


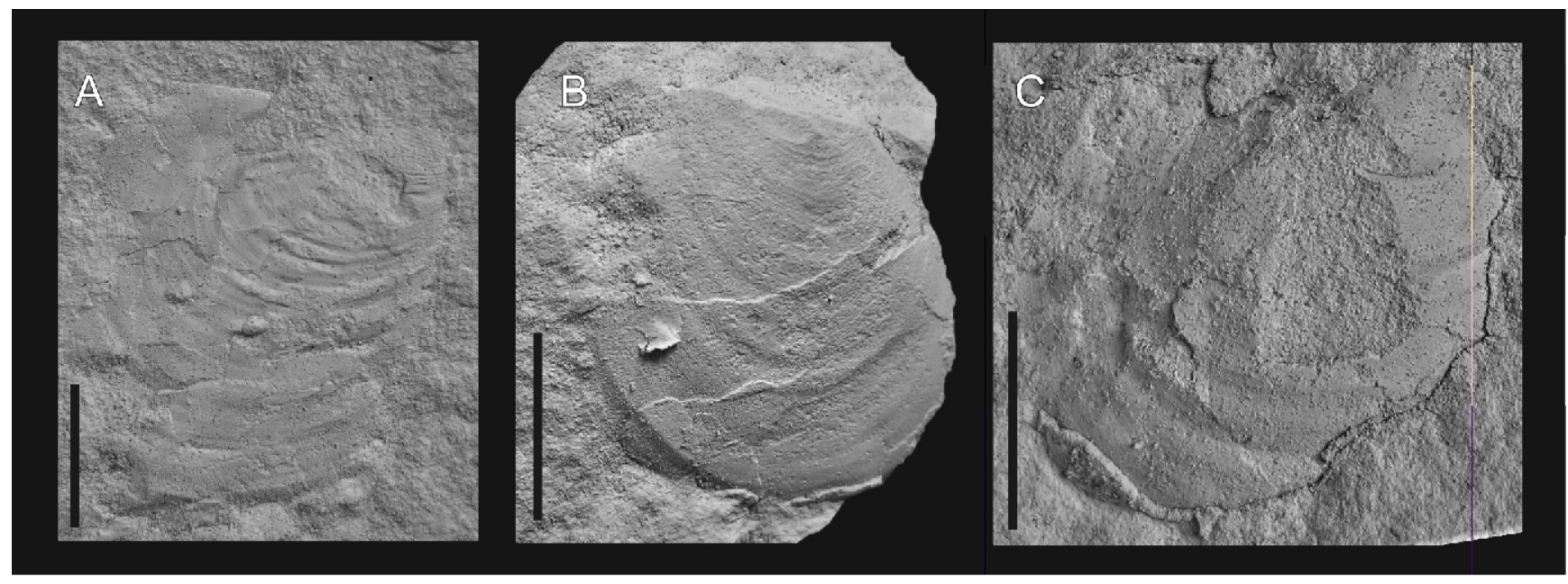

Fig. 17A-C - Platyceramus ex gr. mantelli (de Mercey; Barrois, 1879, MWGUW Zl/87/061-063)

\section{Scale bar - $1 \mathrm{~cm}$, MWGUW ZI/87/XX - museum numbers}

niacian ammonite reported from England, France, Germany, Austria and Romania (Summesberger, 1992; Kennedy and Gale, 2015).

The genus Peroniceras is a cosmopolitan Coniacian taxon (Kennedy, 1984). Peroniceras tridorsatum (Schlüter, 1867; Fig. 19B) occurs in the eponymous (Middle Coniacian) and the Gauthiericeras margae (Upper Coniacian) zones in Saxony (Germany), Poland and Romania (Kennedy, 1984a, b; Szász and Ion, 1988; Kaplan and Kennedy, 1994).

\section{ENVIRONMENTAL INTERPRETATION}

The Visterna, Caugagia and Baia 2 Quarry sections represent the majority of the Upper Turonian to Middle Coniacian succession in North Dobrogea. Although the succession studied does not cover the entire interval (due to some observational gaps), our work on the fossil record, biostratigraphy, and microfacies enables an assessment of palaeoenvironmental conditions and palaeogeographic evolution of the Babadag Basin during the Late Turonian-Middle Coniacian.

\section{UPPER TURONIAN}

The base of the succession (Visterna, Unit 1) is dominated by planktonic foraminifera. This is followed by an interval (Visterna, Units 1-4) with a gradual, significant rise in the percentage of benthic foraminifera (mainly of the genus Textularia and Arenobulimina, both agglutinating forms), leading to the dominance of benthic forms (see Table 3). The trend reverses in the higher parts of the section (Visterna, Units 5-10); planktonic forms begin to dominate again. In general, the percentage of benthic foraminifera appears to parallel the amount of siliciclastic material present in the bulk sample. Among benthic foraminifera, agglutinating forms dominate. EDS analyses confirm that - in most cases - calcareous foraminifera shells are made of primary calcite and were not dissolved during diagenetic processes. Moreover, benthic calcareous forms co-occur with agglutinating forms; therefore, the abundance of the agglutinating foraminifera appears to be due to environmental conditions, as opposed to diagenetic controls. An exception are foraminifera from Unit 3 (sample V18B) and Unit 5 (sample $\mathrm{V} 27 \mathrm{~A}$ ) in which calcareous planktonic foraminifera are pre- served as silicified moulds (including pore fillings; the planktonic forms are almost exclusively present), with dissolved shells (Fig. 20).

It is well-known that very shallow or very deep, low $\mathrm{pH}$ environments allow for the dominance and high abundances of agglutinating foraminifera (Murray and Alve, 2011; Dubicka and Machalski, 2016; Walaszczyk et al., 2016a). In the Visterna section, agglutinating forms commonly co-occur with well preserved, keeled planktonic forms, which may indicate a higher environmental tolerance than in contemporary forms (Murray and Alve, 2011) of Late Cretaceous agglutinating foraminifera. This conjecture is supported by: (1) good preservation of agglutinating forms' shells, which excludes the possibility of significant transportation prior to deposition; (2) preservation of the primary composition and structure of planktonic foraminifera shells, which excludes the possibility that the relative enrichment in the frequency of the agglutinating forms was a result of the dissolution of planktonic forms; and (3) low organic matter contents in the samples examined for dinoflagellate cysts, which is evidence of normal, oxic conditions at the seawater-sediment interface. The lack of primary calcite in foraminifera shells from samples $\mathrm{V} 18 \mathrm{~B}$ and $\mathrm{V} 27 \mathrm{~A}$, and the condensation of these microorganisms in sample V27A is interpreted as a consequence of diagenetic dissolution and washout of carbonates from originally calcareous strata.

Distinct Tethyan influences in the Late Turonian of the Babadag Basin may be inferred based on the comparison of foraminiferal assemblages from the Babadag and from the Middle Vistula River section (Central Poland; see Peryt, 1980; Walaszczyk and Peryt, 1998). Marginotruncana cf. marianosi, M. schneegansi and M. tarfayaensis - all found in the Babadag Basin - are typical Tethyan species (see e.g., Ardestani et al., 2012; Kazemi et al., 2014; Chen et al., 2015; Reolid et al., 2015). Intervals with clear dominance of calcareous algae may be considered evidence for repeated eutrophic events.

During the Late Turonian, the Babadag Basin constituted a relatively shallow, nearshore to offshore environmental setting. Several lines of evidence support this supposition: for example, terrigenous quartz is relatively abundant; and, there is a diverse abundance of benthic organisms (foraminifera, echinoids, bivalves, brachiopods, algae, corals, bryozoans and ostracods). A shallowing event is recorded in the middle part of the Turonian succession (units 2-4 of the Visterna section; 


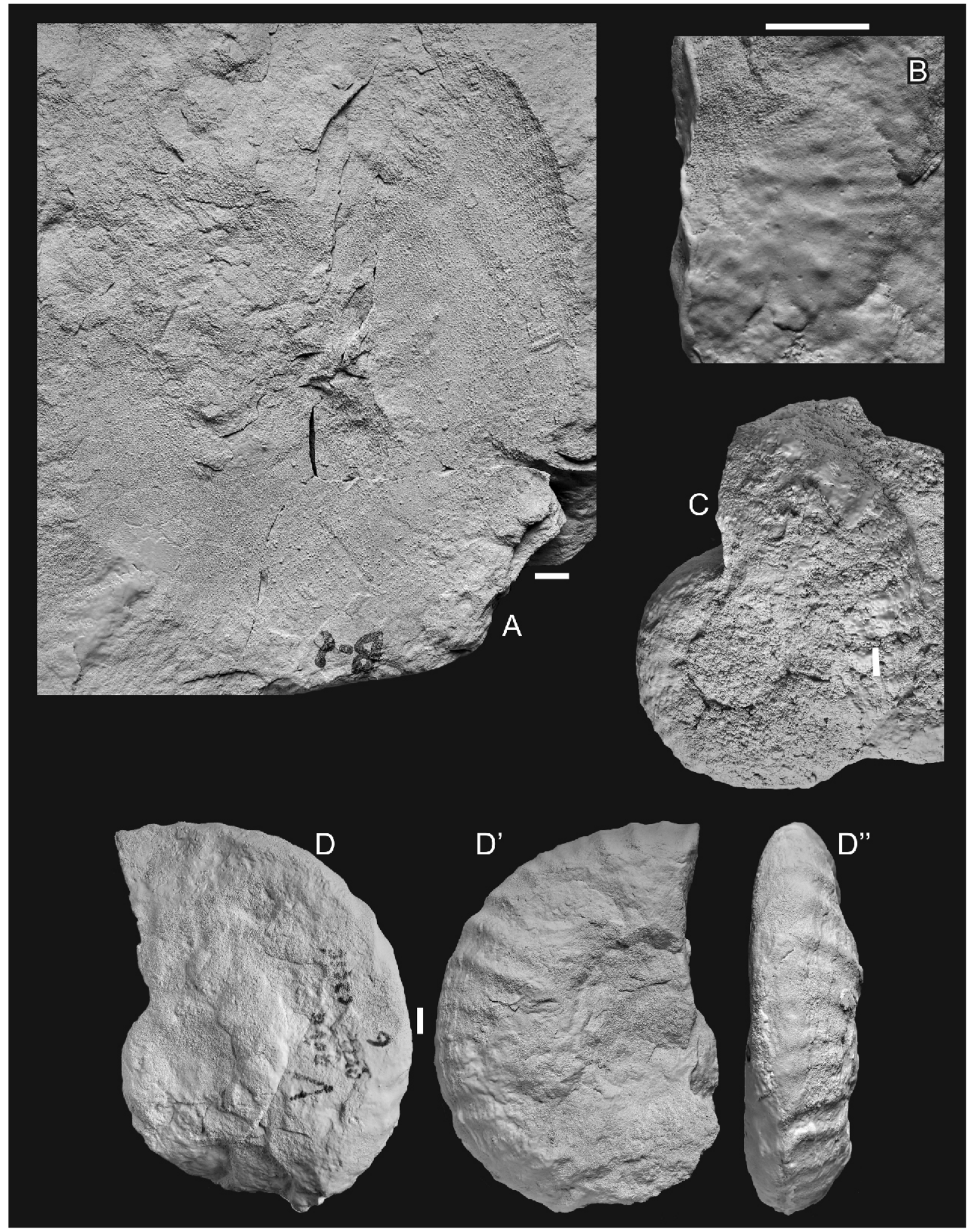

Fig. 18. Upper Turonian and Middle Coniacian ammonites of the Babadag Basin

A - Mesopuzosia cf., MWGUW ZI/87/001; B - Scaphites ex gr. fisheri Riedel, 1931, MWGUW ZI/87/028; C, D - Lewesiceras mantelli (Wright and Wright, 1951), MWGUW ZI/87/002-004; scale bar - $1 \mathrm{~cm}$; MWGUW ZI/87/XX - museum numbers 


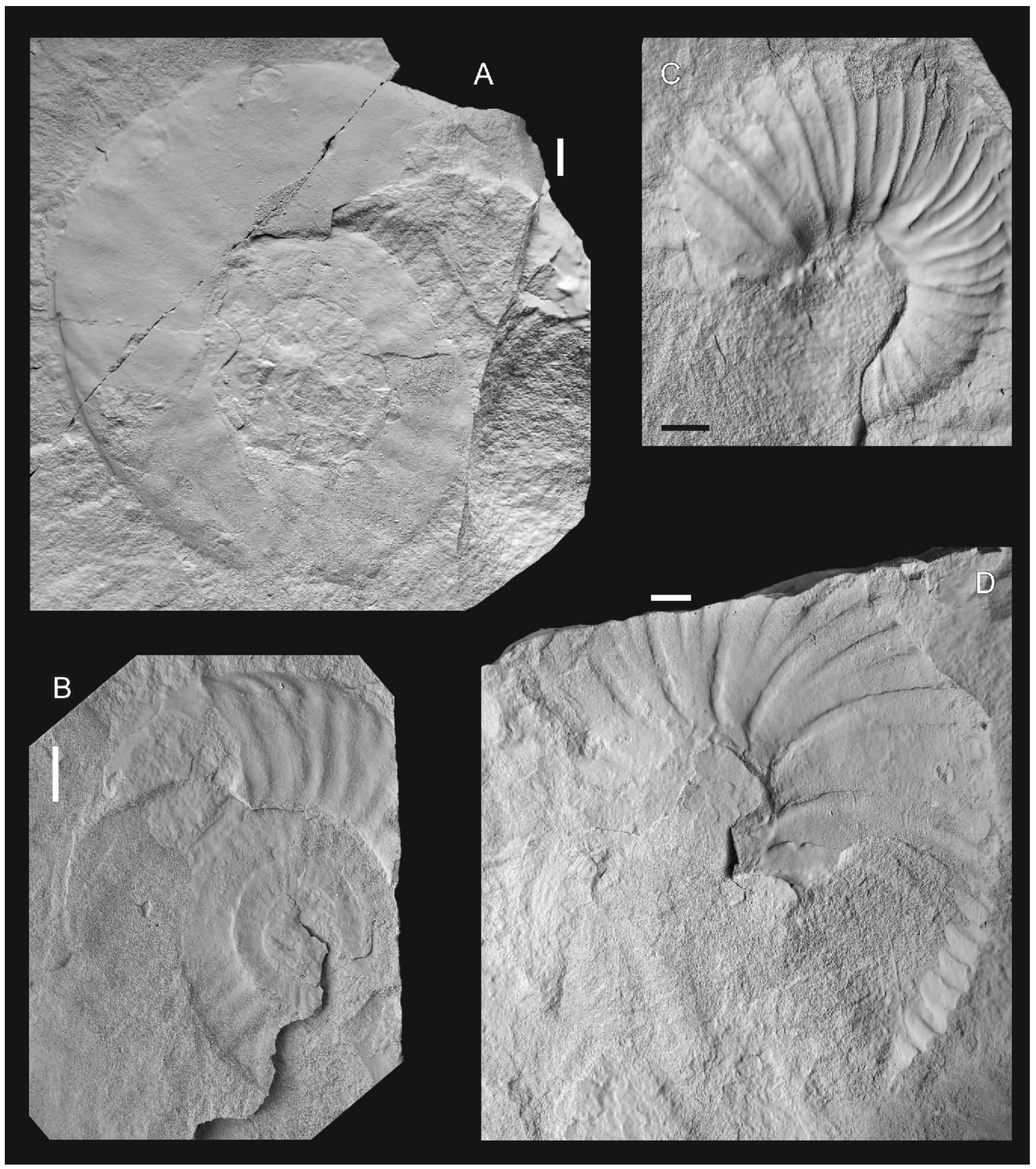

Fig. 19. Middle Coniacian ammonites of the Babadag Basin

A - Peroniceras sp., MWGUW ZI/87/016; B - Peroniceras tridorsatum (Schlüter, 1867), MWGUW ZI/87/017; C, D - Nowakites sp., MWGUW ZI/87/019-020; scale bar - $1 \mathrm{~cm}$; MWGUW ZI/87/XX - museum numbers 

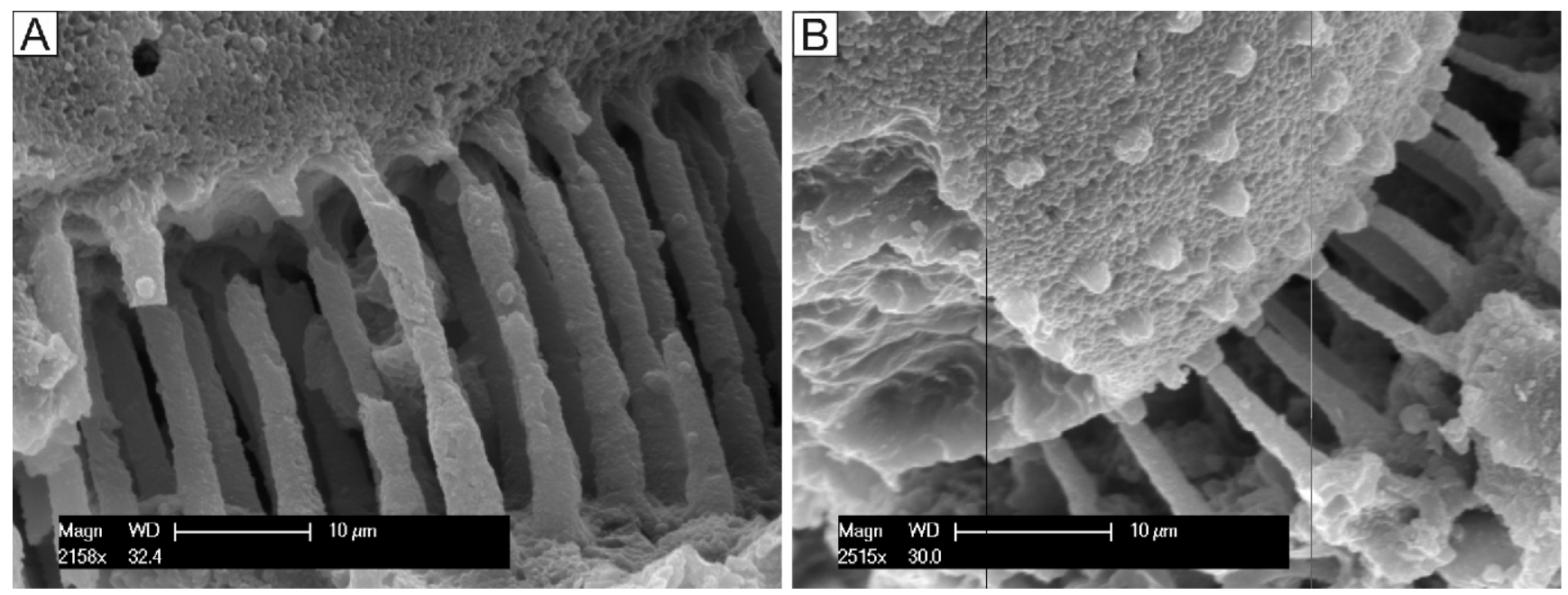

Fig. 20. Dissolved calcareous foraminiferal tests with silicified moulds and pores fill-in (A and B)

$$
\text { Scale bar }-10 \mu \mathrm{m}
$$

Fig. 21), characterized by a significant increase in the abundance and grain size of detrital quartz. This Middle-Late Turonian shallowing (emergence?) event is consistent with the Late Turonian trends recorded in many European and American sections (Hancock and Kauffman, 1979; Hancock, 1989; Hart, 1990; Hancock and Walaszczyk, 2004; Haq, 2014) and is thus interpreted with respect to the Late Turonian eustatic regression. However, it may be also interpreted as a synrift event, related to Peceneaga-Camena fault activity triggered by the Western Black Sea basin opening (see Krezsek et al., 2018).

\section{LOWER CONIACIAN}

A marine shelf, off-shore environment is suggested by: (1) very limited terrigenous input and sparse quartz content; (2) small detrital grain size and (3) a fossil record dominated by inoceramids and open-marine, planktonic foraminifera.

\section{MIDDLE CONIACIAN}

No characteristic Tethyan species occur in the Middle Coniacian of the succession studied; the foraminiferal assemblages are in line with those of the transitional province (Pożaryska and Peryt, 1979; Peryt, 1980; Walaszczyk and Peryt, 1998). The microfacies succession documented in the Baia 2 section indicates a significant rise and subsequent fall in detrital and quartz content. An interpretation of this trend in terms of bathymetric changes is supported by concomitant changes in fossil assemblages, and suggests that a regressive-transgressive cycle was responsible.

In general, the Middle Coniacian, as represented by the Baia 2 succession, represents a pelagic environment. This environmental interpretation is based on a very sparse content of very fine-grained quartz, the presence of laminations in parts of the succession, and by the fossil assemblage limited almost exclusively to algae, sponges and foraminifera. A shallowing event (at its maximum in the $\mathrm{B}_{2} 11$ sample) is recorded in the middle part of the succession (units 2-4), as indicated by cross-bedding, ripple marks, a distinct increase in quartz content, and intraformational breccia $\left(\mathrm{B}_{2} 11\right.$ sample, Unit 3$)$. The breccia matrix is rich in foraminifera, echinoids, bivalves, bryozoans, ostracods, sponges and algae. A tectonic trigger of the breccia formation cannot be excluded.

\section{CONCLUSIONS}

Three quarry sections - Visterna, Caugagia, and Baia 2 provide a significant and meaningful insight into the Upper Turonian-Middle Coniacian succession of the Babadag Basin (with the minor caveat that some observational gaps unfortunately exist between these sections).

The base of the succession may be securely assigned to the early Late Turonian. Based on an inoceramid assemblage [composed of Inoceramus ex gr. lamarcki Parkinson, 1818, Mytiloides cf. striatoconcentricus (Gümbel, 1868), and Inoceramus aff. perplexus Whitfield, 1877], it may be safely located in the Inoceramus perplexus and Mytiloides striatoconcentricus zones. The Lower Coniacian, although poorly exposed at present, yielded a rich Cremnoceramus fauna, which places this portion of the succession in the Cremnoceramus deformis erectus and Cremnoceramus deformis deformis zones, of the early and middle parts of the Early Coniacian. The Middle Coniacian is denoted by the ammonite Peroniceras tridorsatum (Schlüter, 1867) and Platyceramus ex gr. mantelli (and the lack of Magadiceramus).

The inoceramid and ammonite biostratigraphic zonations are in agreement with age assignments based on foraminiferal assemblages. The zones recognized of Helvetoglobotruncana helvetica, Marginotruncana coronata/Marginotruncana schneegansi, and Marginotruncana sinuosa and/or Dicarinella concavata are standard zones in this interval. The planktonic foraminifera reveal a distinct Tethyan influence.

Fig. 21. Integrated biostratigraphy, microfacies, quartz content and relative sea level changes in the Late TuronianMiddle Coniacian in the southeastern part of the Babadag Basin

C. def. - Cremnoceramus deformis; V. - Volviceramus; amm. zonation - ammonite zonation; inoc. zonation - inoceramid zonation; foram. zonation - foraminiferal zonation; other explanations as in Figures 5 and 8 


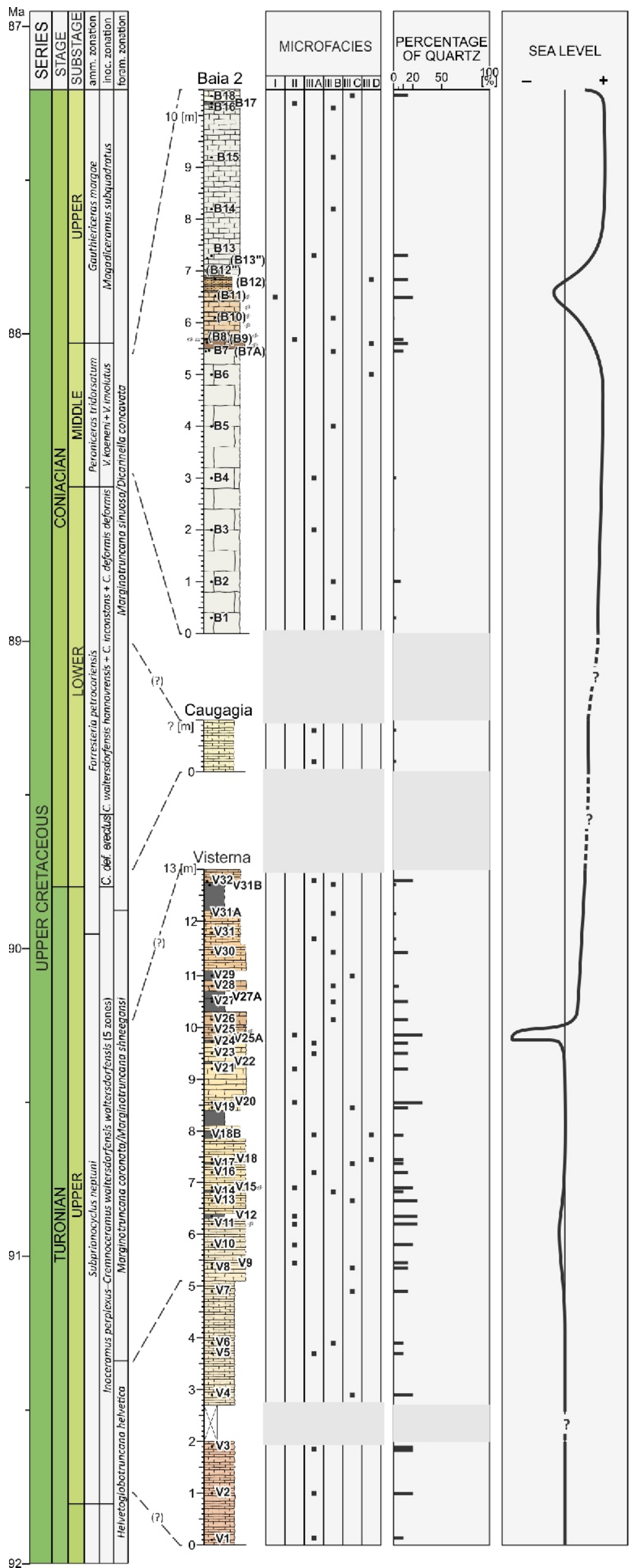


During the Late Turonian-Middle Coniacian the Babadag Basin was a relatively shallow sea. It was located close to source areas of terrigenous material, and thus was sensitive to detrital input. Microfacies and fossil assemblage analyses reveal that generally stable bathymetric conditions held throughout this interval, with two regression events, one in the Middle-Late Turonian and one in the Middle Coniacian. The Middle-Late Turonian regression may be an expression of the main Late Turonian eustatic trough. The enhancement of these bathymetric trends by local tectonic events - the opening of the western Black Sea basin and activity of the Peceneaga-Camena Fault - is quite probable.

Acknowledgements. We would like to warmly thank Dr. Z. Dubicka (University of Warsaw) for invaluable remarks, discussion and help with foraminifera studies, and Prof. J. Kennedy (Oxford, UK) for ammonite determinations. Our warmest thanks go to Dr. A. Żylińska (University of Warsaw) and W. Wierny, M.Sc., for their help during our 2016 fieldwork. We would like to thank Dr. P. Ziółkowski (University of Warsaw) for access to the laboratories of the European Center for Geological Education (Chęciny, Poland), where thin sections were prepared. Last, but not least, we would like to give thanks to the reviewers of this manuscript, Prof. M. Stoica (University of Bucharest) and Dr. A. Jurkowska (University of Science and Technology in Cracow). J. Todes (University of Warsaw) read a final version of the paper and made a number of valuable corrections and comments. The project entitled, "The facies characteristics, stratigraphy and biogeography of the early Late Cretaceous (Turonian-Coniacian) of the Babadag Basin, SE Romania", was financially supported by the Institute of Geology of the Faculty of Geology of the University of Warsaw through grant no. BST176802.

\section{REFERENCES}

Anastasiu, V., 1898. Contribution a l'Etude Geologique de la Dobrogea (Roumanie). Terrains secondaires. G. Carré et C. Naud, Paris.

Ardestani, M.S., Vahidinia, M., Sadeghi, A., Arz, J.A., Dochev, D., 2012. Integrated biostratigraphy of the Upper Cretaceous Abderaz Formation of the East Kopet Dagh Basin (NE Iran). Geologica Balcanica, 1-3: 21-37.

Atanasiu, V., 1940. Privire generală asupra geologiei Dobrogei (in Romanian). Institutul de Arte Grafice "Brawo", laşi.

Băncilă, I., Neagu, T., Muţiu, R., Dragastan, O., 1997. Jurassic-Cretaceous stratigraphy and tectonic framework of the Romanian Black Sea offshore. Revue Roumaine de Géologie, 41: 65-76.

Bengtson, P. (compiler), 1996. The Turonian stage and substage boundaries. Bulletin de l'Institut Royal des Sciences Naturelles de Belgique, 66 (supplement): 69-79.

Boote, D.R.D., 2018. The geological history of the Istria "Depression", Romanian Black Sea shelf: tectonic controls on second-/third-order sequence architecture. Geological Society Special Publications, 464: 169-209.

Bucur, I.I., Baltreş, A., 2002. Cenomanian microfossils in the shallow water limestones from Babadag Basin: biostratigraphic significance. Studia Universitatis Babeş-Bolyai, Geologia, Special issue, 1: 79-95

Burchfiel, B.C., Bleahu, M., 1976. Geology of Romania. The Geological Society of America Special Papers, Denver.

Chen, X., Wang, C., Wu, H., Kuhnt, W., Jia, J., Holbourn, A., Ma, C., 2015. Orbitally forced sea-level changes in the upper Turonian-lower Coniacian of the Tethyan Himalaya, southern Tibet. Cretaceous Research, 56: 691-701.

Compton, R.R., 1962. Manual of Field Geology. John Wiley \& Sons, Inc., New York.

Damian, R., Lazăr, I., 2005. The stratigraphic position of the Late Cretaceous inoceramids from the Olănești-Cheia basin (Southern Carpathians). Acta Palaeontologica Romaniae, 5: 95-106.

Dochev, D., 2015. Turonian (Upper Cretaceous) inoceramid bivalves of the genus Mytiloides from the Sredna Gora Mountains, north-western Bulgaria. Acta Geologica Polonica, 65: 101-119.

Dubicka, Z., Machalski, M., 2016. Foraminiferal record in a condensed marine succession a case study from the Albian and Cenomanian (mid-Cretaceous) of Annopol, Poland. Geological Magazine, 3: 1-20.

Dubicka, Z., Peryt, D., 2012. Foraminifers and stable isotope record of the Dubivtsi chalk (upper Turonian, Western Ukraine) palaeoenvironmental implications. Geological Quarterly, 56 (1): 199-214.
Ernst, G., Schmid, F., Seibertz, E., 1983. Event-Stratigraphie im Cenoman und Turon von NW-Deutschland. Zitteliana, 10: $531-554$.

Gale, A.S., Kennedy, W.J., Lees, J.A., Petrizzo, M.R., Walaszczyk, I., 2007. An integrated study (inoceramid bivalves, ammonites, calcareous nannofossils, planktonic foraminifera, stable carbon isotopes) of the Ten Mile Creek section, Lancaster, Dallas County, north Texas, a candidate Global boundary Stratotype Section and Point. Acta Geologica Polonica, 57: 113-160.

Grădinaru E., 1988. Jurassic sedimentary rocks and bimodal volcanics of the Cîrjelari-Camena Outcrop Belt: evidence for a transtensile regime of the Peceneaga-Camena Fault. Studii şi Cercetări de geologie, geofizică, geografie, Seria Geologie, 33: 97-121.

Grădinaru, E., 1995. Mezozoic rocks in North Dobrogea: an overview. In: IGCP Project No. 369, Comparative Evolution of PeriTethyan Rift Basins (eds. M. Săndulescu and E. Grădinaru): 1-4. Central and North Dobrogea, Romania, October 1-4, 1995. Field Guidebook. Bucharest.

Grădinaru, E., 2004. Vraconian age of the Enisala limestone from the Babadag Basin (North Dobrogea orogene): Lepthoplites enisalaensis new species. Studii şi Cercetări de Geologie, 47 1-63.

Grădinaru E., 2006. Geologia terenurilor triasice şi jurasice din Zona Peceneaga-Camena (in Romanian). Ars Docendi, Bucureşti.

Grădinaru, E., Bărbulescu, A., Owen, E.F., 2006. Latest Albian (Vraconian) brachiopod fauna from North Dobrogea (Romania): taxonomy, palaeoecology and palaeobiogeography. Acta Geologica Polonica, 56: 67-88.

Hancock, J.M., 1989. Sea-level changes in the British region durin the Late Cretaceous. Proceedings of the Geologists' Association, 100: 565-594

Hancock, J.M., Kauffman, E.G., 1979. The great transgressions of the Late Cretaceous. Journal of the Geological Society, 136 175-186.

Hancock, J.M., Walaszczyk, I., 2004. Mid-Turonian to Coniacian changes of sea level atound Dallas, Texas. Cretaceous Research, 25: 459-471.

Haq, B.U., 2014. Cretaceous eustasy revisited. Global and Planetary Change, 113: 44-58.

Hart, M.B., 1990. Cretaceous sea level changes and global eustatic curves; evidence from SW England. Proceedings of the Ussher Society, 7: 268-272. 
Huber, B.T., Petrizzo, M.R., 2014. Evolution and taxonomic study of the Cretaceous planktic foraminiferal genus Helvetoglobotruncana Reiss, 1956. Journal of Foraminiferal Research, 44 40-57.

Ion, J., Szász, L., 1994. Biostratigraphy of the Upper Cretaceous of Romania. Cretaceous Research, 15: 59-87.

Ion, J., Antonescu, E., Melinte, M.C., Szász, L., 1997. Upper Cretaceous integrated biostratigraphy of Romania. Acta Palaeontologica Romaniae, 1: 241-253.

Ion, J., Antonescu, E., Melinte, M.C., Szász, L., 2004. Integrated biostratigraphy of the Turonian of Romania. Acta Palaeontologica Romaniae, 4: 151-161.

Ionesi, L., 1994. Geologia unităţilor de platformă şi a orogenului Nord-Dobrogean (in Romanian). Editura Tehnică, Bucureşti.

Jerram, D.A., Cheadle, M.J., Hunter, R.H., Elliott, M.T., 1996. The spatial distribution of grains and crystals in rocks. Contributions to Mineralogy and Petrology, 125: 60-74.

Kaplan, U., Kennedy, W.J., 1994. Ammoniten des westfalischen Coniac. Geologie und Paläontologie in Westfalen, 31: 1-155.

Kauffman, E.G., Kennedy, W.J., Wood, C.J., 1996. The Coniacian stage and substage boundaries. Bulletin de l'Institut Royal des Sciences Naturelles de Belgique, Science de la Terre, 66: 81-94.

Kazemi, A., Sadeghi, A., Adabi, M.H., 2014. Biostratigraphy of the Surgah formation in Kuh-e-Surgah and correlation with Tang-e-Gerab (West of Iran). Arabian Journal of Geosciences, 7: 655-664.

Kennedy, W.J., 1984a. Systematic Palaeontology and stratigrapic distribution of the ammonite faunas of the French Coniacian Special Papers in Palaeontology, 31: 1-160.

Kennedy, W.J., 1984b. Ammonite faunas and the "standard zones" of the Cenomanian to Maastrichtian Stages in their type areas, with some proposals for the definition of the stage boundaries by ammonites. Bulletin of the Geological Society of Denmark, 33 147-161.

Kennedy, W.J., Christensen, W.K., 1991. Coniacian and Santonian ammonites from Bornholm, Denmark. Bulletin of the Geological Society of Denmark, 38: 203-226.

Kennedy, W.J., Bilotte, M., Melchior, P., 1995. Ammonite faunas, biostratigraphy and sequence stratigraphy of the ConiacianSantonian of the Corbières (NE Pyrénées). Bulletin des Centres de Recherches Exploration-Production Elf Aquitaine, 19 377-499.

Kennedy, W.J., Gale, A., 2015. Late Turonian ammonites from Haute-Normandie, France. Acta Geologica Polonica, 65: 507-524.

Krezsek, C., Bercea, R.-I., Tari, G., Ionescu, G., 2018. Cretaceous sedimentation along the Romanian margin of the Black Sea: in ferences from onshore to offshore correlations. Geological Society Special Publications, 464: 211-245.

Macovei, G., 1906. Note sur un Pachydiscus du Cretacé supérieur de Babadag (Dobrogea). Annales Scientifiques de l'Universite de Jassy, 4: 78-81.

Macovei, G., Atanasiu, I., 1934. L'évolution géologique de la Roumanie. Crétacé. Anuarul Institutului Geologic al României, 16: $65-280$

Mirăuţă, O., Mirăuţă, E., 1964. Cretaciul superior si fundamentul Bazinului Babadag (Dobrogea) (in Romanian). Anuarul Comitetului Geologic al României, 33: 343-380.

Murray, J.W., Alve, E., 2011. The distribution of agglutinated foraminifera in NW European seas: baseline data for the interpretation of fossil assemblages. Palaeontologica Electronica, 14: 1-41.

Mutihac, V., Dragastan, O., Lãcãtuşu, A., 1972. Cretacicul inferior din Dobrogea de Nord (in Romanian). Studii şi Cercetări de Geologie, Geofizică şi Geografie, Seria Geologie, 17: 77-85.

Ogg, J.G., Hinnov, L.A., 2012. The geologic time scale - Cretaceous. In: The Geologic Time Scale (eds. J.G. Ogg and L.A. Hinnov): 793-853. Elsevier, Amsterdam, London, Cambridge.

Ogg, J.G., Hinnov, L.A., Gradstein, F.M., 2016. A concise geologic time scale - Cretaceous. In: A Concise Geologic Time Scale (eds. J.G. Ogg, L.A. Hinnov and F.M. Gradstein): 167-186. Elsevier,; Amsterdam, London, Cambridge.

Peryt, D., 1980. Planctonic foraminifera zonation of the Upper Cretaceous in the Middle Vistula river Valley, Poland. Palaeontologica Polonica, 41: 3-101

Peters, K.E., 1867. Grundlinien zur Geographie und Geologie de Dobrudscha. Denkschriften der Mathematisch-Nathurwissenschaftlichen Klasse der Kaiserlichen Akademie der Wissenschaften, 27: 83-207.

Pettijohn, F.J., Potter, P.E., Siever, R., 1987. Sand and Sandstone. Springer-Verlag, Berlin

Pożaryska, K., Peryt, D., 1979. The Late Cretaceous and Early Paleocene foraminiferal "Transition Province" in Poland. Aspekte der Kreide Europas, International Union of Geological Sciences, Series A, 6: 293-303.

Remin, Z., 2010. Upper Coniacian, Santonian, and lowermost Campanian ammonites of the Lipnik-Kije section, central Poland - taxonomy, stratigraphy, and palaeogeographic significance. Cretaceous Research, 31: 154-180.

Remin, Z., Dubicka, Z., Kozłowska, A., Kuchta, B., 2012. A new method of rock disintegration and foraminiferal extraction with the use of liquid neutrogen [ $\left.\mathrm{LN}_{2}\right]$. Do conventional methods lead to biased paleoecological and paleoenvironmental interpretations? Marine Micropaleontology, 86-87: 11-14.

Reolid, M., Sánchez-Quińónez, C.A., Alegert, L., Molina, E., 2015. Palaeoenvironmental turnover across the Cenomanian-Turonian transition in Oued Bahloul, Tunisia: foraminifera and geochemical proxies. Palaeogeography, Palaeoclimatology, Palaeoecology, 417: 491-510.

Riedel, L., 1931. Zur Stratigraphie und Faciesbilding im Oberemscher und Untersenon am Südrande des Beckens von Münster. Jahrbuch der Königlich Preußischen Geologischen Landesanstalt und Bergakademie, 51: 605- 713.

Robinson, A.G., 1997. Tectonic elements of the Black Sea Region. AAPG Memoir, 68: 1-6.

Săndulescu, M., 1984. Geotectonica României (in Romanian). EdituraTehnică, Bucureşti.

Săndulescu, M., 1994. Overview on the geology of the Carpathians. In: ALCAPA II Field Guidebook "South Carpathians and Apuseni Mountains" (ed. M. Săndulescu): 3-15. Romanian Journal of Tectonics and Regional Geology, Bucureşti.

Săndulescu, M., Kräutner, H., Borcos, M., Năstăseanu, S. Patrulius, D., Ştefănescu, M., Ghenea, C., Lupu, M., Savu, H., Bercia, I., Marinescu, F., 1978. Atlas Geologic Foaia Nr. 1. Harta Geologică Republica Socialistă România. Institutul de Geologie şi Geofizică, Bucureşti.

Simionescu, I., 1914. Le Néocrétacé de Babadag (Dobrogea). Académie Roumaine, Bulletin de la Section Scientifique, 2: 67-72.

Simionescu, I., 1927. Aperçu géologique sur la Dobrogea. In: Guide des excursions (eds. G. Macovei, I. Atanasiu, L. Mrazec, E. Jekelius, D.M. Preda, O. Protescu, S. Athanasiu and I. Simionescu): 353-378. Association pour l'avancement de la géologie des Carpates. Cultura Naţională; Bucureşti.

Summesberger, H., 1992. Ammoniten aus dem Turon (Oberkreide) der Nördlichen Kalkalpen (Österreich). Annalen des Naturhistorisches Musem in Wien, 94: 103-133.

Szász, L., 1981. Contributions à l'étude des ammonites coniaciens de la Roumanie. Mémoires, Institute de Géologie et de Géophysique, 30: 93-114.

Szász, L., 1982. Sur la présence des ammonites cénomaniennes dans le Basin de Babadag (Dobrogea de Nord). Dări de seamă ale Şedinţelor, Institutul de Geologie şi Geofizică, 66: 27-44.

Szász, L., 1985. Contributions to the study of the inoceramus fauna of Romania. Coniacian Inoceramus from the Babadag Basin (North Dobrogea). Mémoires, Institut de Géologie et de Géophysique, 32: 137-184.

Szász, L., Ion, J., 1988. Crétacé supérieur du Bassin de Babadag (Roumanie). Biostratigraphie intégrée (ammonites, inocérames, foraminifères planctoniques). Mémoires, Institut de Géologie et de Géophysique, 33: 91-149. 
Szász, L., Lăcătuşu, A., 1976. Contribuţii la studiul amoniţilor din Neocretacicul bazinului Babadag (Dobrogea de Nord) (in Romanian). Dări de seamă ale Şedinţelor, Institutul de Geologie şi Geofizică, 60: 204-230.

Szász, L., Mihăilescu, N., Ghenea, A., Ghenea, C., Vlad, V., Tiepac, E., 1980. Harta Geologică Republica Socialistă România, Sheet 153 a Babadag, scara 1:50 000 (in Romanian). Institutul de Geologie şi Geofizică, Bucureşti.

Szász, L., Mirăuţă, E., Mureşan, M., Vlad, V., Radovici, E., 1981. Harta Geologică Republica Socialistă Romănia, Sheet 153 a Jurilovca, scara 1:50 000 (in Romanian). Institutul de Geologie şi Geofizică, Bucureşti.

Świdrowska, J., Hakenberg, M., Poluhtovič, B., Seghedi, A., Višnâkov, I., 2008. Evolution of the mesozoic basins on the southwestern edge of the east european craton (Poland, Ukraine, Moldova, Romania). Studia Geologica Polonica, 130: $3-130$.

Tröger, K.-A., 1989. Problems of Upper Cretaceous inoceramid biostratigraphy and paleobiogeography in Europe and western Asia. In: Cretaceous of the Western Tethys (ed. J. Wiedmann): 911-930. E. Schweizer'bartsche Verlagsbuchhandlung, Stuttgart.

Walaszczyk, I., Cobban, W.A., 2000. Inoceramid faunas and biostratigraphy of the Upper Turonian-Lower Coniacian of the Western Interior of the United States. Special Papers in Palaeontology, 64: 1-119.

Walaszczyk, I., Cobban, W.A., 2006. Palaeontology and biostratigraphy of the Middle-Upper Coniacian and Santonian inoceramids of the US Western Interior. Acta Geologica Polonica, 56: 241-348.

Walaszczyk, I., Peryt, D., 1998. Inoceramid-foraminiferal biostratigraphy of the Turonian through Santonian deposits of the Middle Vistula Section, Central Poland. Zentralblatt für Geologie und Paläontologie Teil I, 11/12: 1501-1513.

Walaszczyk, I., Wood, C.J., 1998. Inoceramids and biostratigraphy at the Turonian/Coniacian boundary; based on the SalzgitterSalder (proposed boundary stratotype) section (Lower Saxony, Germany), and the Słupia Nadbrzeżna section (central Poland). Acta Geologica Polonica, 48: 395-434.

Walaszczyk, I., Wood, C.J., 2018. Inoceramid bivalves from the Coniacian (Upper Cretaceous) of the Staffhorst shaft (Lower Saxony, Germany) - stratigraphical significance of a unique succession. Cretaceous Research, 87: 226-240.

Walaszczyk, I., Wood, C.J., Lees, J.A., Peryt, D., Voigt, S., Wiese, F., 2010. The Salzgitter-Salder Quarry (Lower Saxony, Germany) and Słupia Nadbrzeżna river cliff section (central Poland): a proposed candidate composite Global Boundary Stratotype Section and Poit for the base of the Coniacian Stage (Upper Cretaceous). Acta Geologica Polonica, 60: 445-477.

Walaszczyk, I., Dubicka, Z., Olszewska-Nejbert, D., Remin, Z., 2016a. Integrated biostratigraphy of the Santonian through Maastrichtian (Upper Cretaceous) of extra-Carpathian Poland. Acta Geologica Polonica, 66: 313-350.

Walaszczyk, I., Plint, A.G., Kennedy, W.J., 2016b. Biostratigraphy and Inoceramus survival across the Cenomanian-Turonian (Cretaceous) boundary in the Ram River section, Alberta, Canada. Acta Geologica Polonica, 66: 715-728.

Ziegler, P.A., 1984. Caledonian and Hercynian crustal consolidation of Western and Central Europe - a working hypothesis. Geologie en Mijnbouw, 63: 93-108.

Ziegler, P.A., 1988. Evolution of the Arctic-North Atlantic and the Western Tethys. American Association of Petroleum Geologists, 43: 1-198. 